IZA DP No. 7826

Volatility and Growth: Governments are Key

Michael Jetter

December 2013 


\title{
Volatility and Growth: Governments are Key
}

\author{
Michael Jetter \\ Universidad EAFIT \\ and IZA
}

\section{Discussion Paper No. 7826 \\ December 2013}

\author{
IZA \\ P.O. Box 7240 \\ 53072 Bonn \\ Germany \\ Phone: +49-228-3894-0 \\ Fax: +49-228-3894-180 \\ E-mail: iza@iza.org
}

Any opinions expressed here are those of the author(s) and not those of IZA. Research published in this series may include views on policy, but the institute itself takes no institutional policy positions. The IZA research network is committed to the IZA Guiding Principles of Research Integrity.

The Institute for the Study of Labor (IZA) in Bonn is a local and virtual international research center and a place of communication between science, politics and business. IZA is an independent nonprofit organization supported by Deutsche Post Foundation. The center is associated with the University of Bonn and offers a stimulating research environment through its international network, workshops and conferences, data service, project support, research visits and doctoral program. IZA engages in (i) original and internationally competitive research in all fields of labor economics, (ii) development of policy concepts, and (iii) dissemination of research results and concepts to the interested public.

IZA Discussion Papers often represent preliminary work and are circulated to encourage discussion. Citation of such a paper should account for its provisional character. A revised version may be available directly from the author. 
IZA Discussion Paper No. 7826

December 2013

\section{ABSTRACT \\ Volatility and Growth: Governments are Key}

There exists a persistent disagreement in the literature over the effect of business cycles on economic growth. This paper offers a solution to this disagreement, suggesting that volatility carries a positive direct effect, but also a negative indirect effect, operating through the insurance mechanism of government size. Theoretically, the net growth effect of volatility is then ambiguous. The paper reveals the underlying endogeneity of government size in a balanced panel of 95 countries from 1961 - 2010. In practice, the negative indirect channel dominates in democracies, but with less power to choose public services in autocratic regimes the positive direct effect takes over. Consequently, volatile growth rates are detrimental to growth in democracies, but beneficial to growth in autocracies. The empirical results suggest that a one standard deviation increase of volatility lowers growth by up to 0.57 percentage points in a democracy, but raises growth by 1.74 percentage points in a total autocracy. These findings point to a crucial intermediating role of governments in the relationship between volatility and growth. Both the size of the public sector and the regime form assume key roles.

JEL Classification: $\quad$ E32, H11, O43, P16

Keywords: economic growth, volatility, business cycles, government size, regime form

Corresponding author:

Michael Jetter

Department of Economics

School of Economics and Finance

Universidad EAFIT

Carrera 497 Sur-50, Avenida Las Vegas

Medellín

Colombia

E-mail: mjetter7@gmail.com 
IZA Discussion Paper No. 7826

December 2013

\section{NON-TECHNICAL SUMMARY}

Whether business cycles are good or bad for economic growth is an evergreen in the economics profession. What has since been unrecognized however is the indirect channel from cycles on growth, operating through government size. Faced with a more volatile overall economic environment, people prefer a stronger public sector for security purposes - but bigger governments in turn lower growth in the short run. This leads to a negative growth externality from volatility.

Revealing this mechanism (volatility $\rightarrow$ public sector $\rightarrow$ growth) carries several implications:

(1) the consequences from business cycles might be easier to predict.

(2) past discrepancies on the net relationship between volatility and growth could be explained. There exists a positive direct effect from volatility on growth in the short run, presumably operating through precautionary savings or creative destruction (see Schumpeter). Disentangling the indirect effect through government size helps to isolate the true effects at work.

(3) the regime form of a country is important when evaluating growth consequences from business cycles. For instance, in autocratic regimes, where people cannot actively choose their extent of the public sector, the indirect channel is cut off. In this case, people cannot react to volatility by increasing their public safety net.

In summary, the relationship between business cycles and economic growth may not be as mysterious as previously thought. Taking into account both direct and indirect effects may allow us to estimate whether this connection is positive or negative in a given country. 


\section{Introduction}

The global financial crisis of 2008 has once again magnified the importance of understanding possible connections between business cycles and economic growth. Ever since Ramey and Ramey (1995) proposed a causal relationship between growth volatility and growth itself, researchers have presented evidence for both negative and positive effects from volatility on growth, as summarized in Döpke (2004). ${ }^{1}$ Finally, other papers argue that there exists no link at all between output volatility and growth (Solow, 1997, Dawson and Stephenson, 1997, and Posch and Wälde, 2011).

This paper provides an explanation for these deep disagreements, uncovering a hidden indirect channel, which needs to be accounted for in order to understand the total net effect. Volatility carries both a positive direct effect on economic growth, but also a negative indirect effect, operating through the size of the public sector. As both mechanisms push in opposite directions, estimating growth in a standard single equation framework can lead to misleading conclusions.

Theoretical foundations for a positive connection between volatility and growth include creative destruction (Schumpeter and Fels, 1939; Philippe and Peter, 1992), an opportunity-cost effect of conducting research in recessions (Saint-Paul, 1993; Aghion and Saint-Paul, 1998), and precautionary savings (Mirman, 1971; Devereux and Smith, 1994). However, volatility also carries another consequence, which has been neglected in the growth context. In times of increased cyclical fluctuations, people turn to the public sector for security (see Rodrik, 1998). Specifically, people may call for a tighter public safety net and choose to pursue government sector jobs over more volatile private sector employment (see Jetter et al., 2013). This implies bigger governments in volatile times, which can in turn lower growth rates in the short run, as resources are being withdrawn from the private sector (Barro and Lee, 1994; Barro, 2001; Afonso and Furceri, 2010). ${ }^{2}$ Theoretically, the sign of the net effect is then ambiguous, as summarized in figure 1.

Using a balanced panel of annual observations for 95 countries from 1961 - 2010, this paper presents evidence for the existence and the importance of the indirect channel of volatility on growth. Growth rate volatility is never a significant predictor of growth in a single equation framework, even after including the usual control variables found by Levine and Renelt (1992) and Mirestean and Tsangarides (2009). However, after addressing the underlying endogeneity of government size in a simultaneous estimation

\footnotetext{
${ }^{1}$ Similar to Ramey and Ramey (1995), Badinger (2010) or Wang and Wen (2011) propose negative growth effects from volatility, whereas Caporale and McKiernan (1998), Canton (2002), or Oikawa (2010) suggest positive growth effects. Imbs (2002), Imbs (2007), and Aghion et al. (2010) argue that volatility and growth could be related in various ways.

${ }^{2}$ In a seminal paper, Rodrik (1998) introduces the thought of citizens demanding stronger public safety nets in the light of uncertainty. There exists an extensive discussion surrounding this theory, as Rodrik (1998) first relates trade openness to volatility, which then raises the demand for public goods. In this chain of arguments, the first link of openness leading causing volatility is heavily debated. The present paper only builds on the second effect of volatility causing people to demand more security from the public sector.
} 


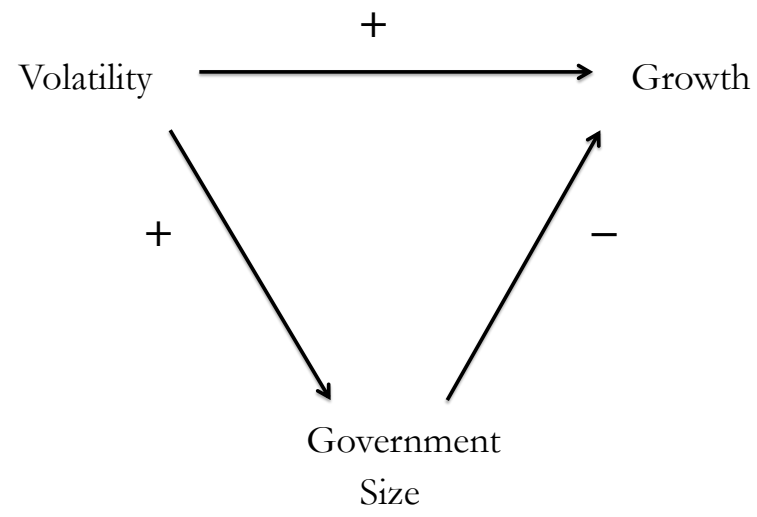

Figure 1: Direct and indirect effect of volatility on growth

framework, both the positive direct and the negative indirect effect receive strong statistical support.

In reality, the relative strength of the two effects varies substantially across countries. Especially the indirect channel of people being able to influence the extent of the public sector relies on the citizen's option to engage in the political process. People can only actively influence public goods provision if they have a say in politics. Indeed, the positive direct effect dominates in autocratic regimes, whereas the negative indirect effect is absent. Once a country evolves into a democratic society the indirect channel gains importance. Regarding growth, this translates to a positive net effect from volatility in autocratic societies, but a negative net effect in democracies.

These findings provide a coherent explanation why previous analyses could not agree on the net effect from volatility on growth. Depending on the mix of regimes in a specific sample, a single estimation framework can produce positive, negative, or no net effects on growth. Thus, taking into account both the indirect channel through government size and the political regime form is important when evaluating potential growth consequences from policies affecting the business cycle. This explains why some papers (Ramey and Ramey, 1995; Martin and Ann Rogers, 2000) find strong negative growth effects from volatility in OECD economies, as these countries are mostly democratic.

In general, these results emphasize the importance of heterogeneity within the determinants of growth, in this case along the lines of political regime form for the effects from volatility. ${ }^{3}$ The surrounding conditions of a country can change sign and magnitudes of growth determinants. In a related context, the political regime form has been found to play an important role in the relationship between trade

\footnotetext{
${ }^{3}$ See Masanjala and Papageorgiou (2008) for differences across regions, specifically Africa. Recently, several nonlinearities have been pointed out in the growth literature, e.g. Reinhart and Rogoff (2010) considering public debt or Henderson et al. (2013) in the context of financial development.
} 
openness and government size (see Sáenz et al., 2013).

The paper proceeds with the methodological setup, followed by a description of the data in section 3 . Section 4 presents the empirical findings and section 5 concludes.

\section{Methodology}

In order to test the effect of growth rate volatility on growth, I first estimate growth in a single estimation framework, including volatility as a regressor. Throughout the paper I use a balanced panel of 95 countries with yearly data from 1961 - 2010. As there exists an open-ended list of potential growth determinants (see Brock and Durlauf, 2001), I use two main reference papers to set up the growth regression: The variables from Levine and Renelt (1992) and Mirestean and Tsangarides (2009). In addition, the empirical analysis includes country fixed effects and country specific time trends, accounting for unique characteristics in terms of history, geography, climate, and development paths of every country. After showing the endogeneity of government size, the paper moves to the suggested three-stage least squares framework (3SLS), estimating growth and government size simultaneously. Throughout the paper, variables starting with $l n$ imply the application of the natural logarithm.

\subsection{OLS Estimation}

The empirical section starts by estimating growth for country $i$ at year $t$, including the volatility of economic growth as a regressor:

$$
g r_{i, t}=\alpha_{1}+\alpha_{2} \operatorname{vol}_{i, t-1}+\alpha_{3} \operatorname{lngov}_{i, t}+\alpha_{4} g r_{i, t-1}+\alpha_{5} \boldsymbol{X}_{\boldsymbol{i}, \boldsymbol{t}-\mathbf{1}}+\alpha_{6} \lambda_{i}+\alpha_{7} \phi_{i, t}+\delta_{i, t}
$$

where $\operatorname{vol}_{i, t-1}$ stands for growth rate volatility, lagged by one year (calculation explained below in section 2.2). Further, $\operatorname{lngov}_{i, t}$ and $\mathrm{gr}_{i, t-1}$ capture the logarithm of total government spending and the growth rate of the previous year. ${ }^{4} X_{i, t-1}$ contains growth determinants suggested by Levine and Renelt (1992) and Mirestean and Tsangarides (2009). Specifically, $X_{i, t-1}$ includes investment (lninv), income $(\operatorname{lng} d p)$, population growth (popgr), life expectancy (lnlife), openness to trade (lnopen), and inflation (lninfl). In order to address the latent reverse causality problem of the growth literature, vol and $X$ are lagged by one year, following suggestions by Temple (1999) and Durlauf et al. (2005). ${ }^{5}$

Absent from the Levine and Renelt variables is only initial human capital, which in a panel setting with fixed effects and country-specific time trends may lose importance anyways. This goes along with

\footnotetext{
${ }^{4}$ Using government size as share of GDP does not change the implication of results, as discussed in section 4.4 .

${ }^{5}$ In terms of lagging the volatility component, Döpke (2004) cannot exclude a potential reverse causality problem in a growth regression. Although imperfect, using lagged values addresses this problem since future growth rates are unlikely to influence past growth volatility.
} 
the more practical reason of data availability for human capital and education variables on a yearly basis. From Mirestean and Tsangarides (2009), the analysis does not include public debt, as missing data would reduce the sample by over 85 percent. Finally, $\lambda_{i}$ and $\phi_{i, t}$ introduce country fixed effects and country-specific time trends, whereas $\delta_{i, t}$ stands for the usual error term. ${ }^{6}$

\subsection{Estimating Volatility}

A crucial aspect of this analysis is how to calculate volatility. For instance, Ramey and Ramey (1995) choose the standard deviation of a country's growth rates over time. However, the problem of this method is that one is stuck with a single observation per country or at least fewer observations if one decides to split the sample. Recently, several filters have become prominent in detrending macroeconomic time series, such as the Hodrick-Prescott (HP) filter or the Baxter-King filter. For instance, Baum (2006) summarizes the discussion surrounding the HP filter, quoting Ravn and Uhlig (2002): “...the HP filter has become a standard method for removing trend movements in the business cycle literature." Although the filter has been subject to heavy criticism, it "has withstood the test of time and the fire of discussion relatively well."

Thus, I use the HP filter to detrend the annual growth rates of every country, following Mills (2000), Döpke (2004), and Afonso and Furceri (2010). To adjust for the sensitivity of the trend portion, the main analysis applies the benchmark value of $\lambda_{H P}=100$, as suggested by Backus and Kehoe (1992) for annual data. ${ }^{7}$ Section 4.4 provides alternatives. As I am only using countries for which all growth rates from 1961 to 2010 are available, each time series contains 50 data points. The result from applying the HP filter is an annual cycle term for each country. As we are interested in volatility in general, not just positive or negative deviations from the trend, I square this value to receive a measurement for the annual volatility component of a country's growth rate (also see Jetter et al., 2013). Finally, in order to facilitate comparability, I divide this value by 100 , which provides the variable $v l_{i, t-1}$.

\subsection{SLS Estimation}

After estimating equation 1, the empirical section presents evidence for the inconsistency of a simultaneous estimation framework, as the Durbin-Wu-Hausman test statistics (see Davidson and MacKinnon, 2001) confirm the endogeneity of government size. The paper then moves to a 3SLS estimation system, where growth and government size are determined simultaneously. The government size regression takes the following form:

$$
\operatorname{lngov}_{i, t}=\beta_{1}+\beta_{2} \operatorname{vol}_{i, t-1}+\beta_{3} g r_{i, t}+\beta_{4} \operatorname{lngov}_{i, t-1}+\beta_{5} Z_{i, t-1}+\beta_{6} \lambda_{i}+\beta_{7} \phi_{i, t}+\epsilon_{i, t},
$$

\footnotetext{
${ }^{6}$ The Hausman test strongly rejects the use of random effects in favor of fixed effects.

${ }^{7}$ For the roots of the HP filter in general, consider Robert and Prescott (1997). For the relevant code in STATA, see Kowal (2005).
} 
where $g r_{i, t}$ captures the effect of growth on government size, following implications from Wagner's Law (see section 2 in Afonso and Furceri, 2010, for a brief discussion or Peacock and Scott, 2000, for more detail). $\operatorname{lngov}_{i, t-1}$ accounts for government size of the previous year. $Z_{i, t-1}$ is a vector containing the remaining control variables of the literature, as summarized by Shelton (2007). Among these are income (lngdp), openness to trade (lnopen), and population size (lnpop). As in the growth regression, I choose lagged explanatory variables, both for consistency and in order to reduce potential issues from reverse causality, as future government size is unlikely to affect the explanatory variables today. ${ }^{8}$

Both equations 1 and 2 are identified by unique variables. For the growth regression, these are lagged growth, investment, population growth, life expectancy, and inflation. In the case of government size, these are lagged government size and total population size. Their suitability as identifying variables is comfortably validated by F-tests for joint insignificance of the unique dependent variables in all respective regressions. Finally, incorporating the seemingly unrelated regression equations model (SUR) accounts for potential correlation of the error terms, extending the 2SLS to a 3SLS system.

\section{Data}

All variables are displayed in table 1 and taken from one of three standard data sources in macroeconomics: The World Bank Development Indicators, the Penn World Tables, and the Polity IV index. On average, the 95 sample countries had an annual growth rate of almost 4 percent. ${ }^{9}$ Figure 2 displays some general growth developments over time and across regions. Standing out as contractions are the oil crisis in the 70s (which especially hit North America and Europe), the Latin American debt crisis in the early 80s, Africa's struggle around 1990, the 1997 Asian financial crisis, and of course the 2008 financial crisis. On the positive side, we observe the Asian boom between 1960 and 1995, driven by the Asian Tigers, and a growth spurt in Africa until the late 70s.

Table 2 sorts all sample countries by their average yearly volatility over the entire time span of 1961 - 2010. We notice that the core European countries, together with South Africa, Sri Lanka, Australia, Guatemala, and Colombia, experienced low volatility. Various African (such as Liberia, the Seychelles, or Rwanda) and some Asian economies (e.g. the Oman) on the other hand experienced many twists and turns. ${ }^{10}$ Further, figure 3 shows the worldwide average volatility over time and a breakdown by continents. We notice major spikes in the mid 60 s and the late 90 s, where the former appears to be driven by African, Asian, and European economies. In general, Asian and European countries managed

\footnotetext{
${ }^{8}$ See for instance Acemoglu et al. (2003) or Klomp and de Haan (2009) for the argument of institutions in general influencing volatility.

${ }^{9}$ The augmented Dickey-Fuller test shows no signs of unit roots being present for most countries, with the exceptions of Greece, Puerto Rico, and Trinidad and Tobago (using one lag and a constant term). Results are available upon request.

${ }^{10}$ See Koren and Tenreyro (2007) for an explanation of why poor countries might have more volatility than rich ones.
} 
Table 1: Summary statistics

\begin{tabular}{|c|c|c|c|c|c|}
\hline Variable & Mean & Std. Dev. & $\mathbf{N}$ & Source & Description \\
\hline$g r$ & 3.98 & 5.83 & 4,750 & WDI & $\begin{array}{l}\text { GDP growth in annual } \\
\text { percent }\end{array}$ \\
\hline vol & 0.238 & 1.87 & 4,750 & Own & $\begin{array}{l}\text { Using the Hodrick- } \\
\text { Prescott filter with } \\
\lambda_{H P}=100 \text { for detrending }\end{array}$ \\
\hline lngov & 21.59 & 2.35 & 4,470 & WDI & $\begin{array}{l}\mathrm{Ln}(\mathrm{GDP} \times \text { government } \\
\text { share } / 100)\end{array}$ \\
\hline $\operatorname{lninv}$ & 21.86 & 2.50 & 4,668 & PWT 7.1 & $\begin{array}{l}\mathrm{Ln}(\mathrm{GDP} \times \text { investment } \\
\text { share } / 100)\end{array}$ \\
\hline $\operatorname{lng} d p$ & 23.46 & 2.31 & 4,750 & WDI & $\begin{array}{l}\text { Ln(total GDP in constant } \\
2000 \text { US } \$)\end{array}$ \\
\hline popgr & 0.02 & 0.022 & 4,750 & PWT 7.1 & $\left(\right.$ oop $\left._{t}-\operatorname{pop}_{t-1}\right) /$ pop $_{t}$ \\
\hline lnopen & 4.02 & 0.63 & 4,530 & WDI & $\begin{array}{l}\text { Ln(trade as percent of } \\
\text { GDP) }\end{array}$ \\
\hline lnlife & 4.11 & 0.20 & 4,671 & WDI & $\begin{array}{l}\text { Ln(life expectancy at } \\
\text { birth) }\end{array}$ \\
\hline $\operatorname{lninfl}$ & 0.12 & 0.29 & 4,750 & WDI & $\begin{array}{ll}\operatorname{Ln}[1 & +\end{array}$ \\
\hline lnpop & 15.91 & 1.85 & 4,750 & WDI & Ln(total population) \\
\hline pol & 1.73 & 7.24 & 4,279 & Polity IV & $\begin{array}{l}\text { Variable polity } 2 \text {, ranging } \\
\text { from }-10 \text { (totally au- } \\
\text { tocratic) to }+10 \text { (total } \\
\text { democracy) }\end{array}$ \\
\hline $\operatorname{vol}_{\lambda_{H P}=6.25}$ & 0.17 & 1.23 & 4,750 & Own & $\begin{array}{l}\text { Using the Hodrick- } \\
\text { Prescott filter with } \\
\lambda_{H P}=6.25 \text { for detrending }\end{array}$ \\
\hline $\operatorname{vol}_{B K}$ & 0.18 & 1.33 & 4,180 & Own & $\begin{array}{l}\text { Using the Baxter-King fil- } \\
\text { ter for detrending }\end{array}$ \\
\hline$g$ & 14.99 & 6.22 & 4,470 & WDI & Government share of GDP \\
\hline$i n v$ & 21.73 & 9.76 & 4,668 & PWT 7.1 & Investment share of GDP \\
\hline
\end{tabular}

Notes: WDI = World Development Indicators (World Bank).

PWT 7.1 = Penn World Table Version 7.1. 
Avg. growth rate worldwide

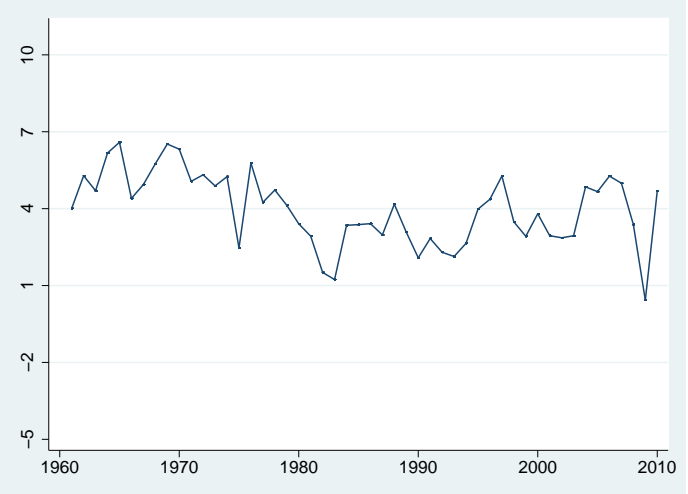

Avg. growth rate

Asia \& Oceania

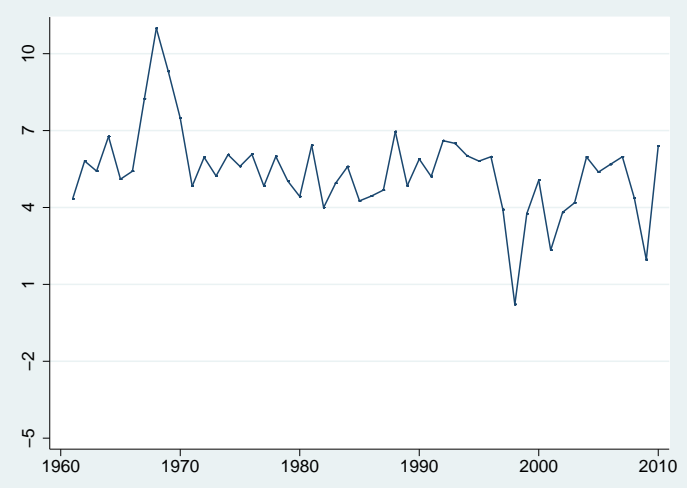

Avg. growth rate North America

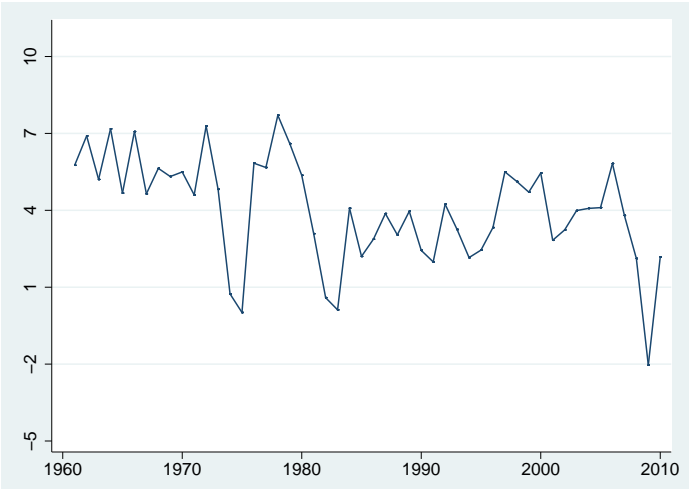

Avg. growth rate Africa

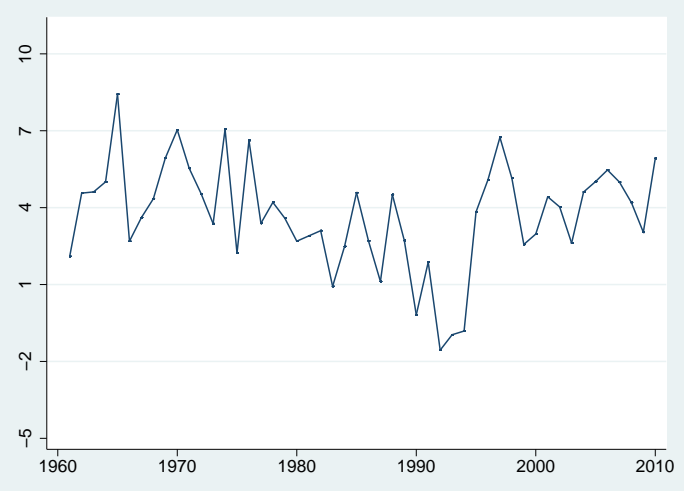

Avg. growth rate Europe

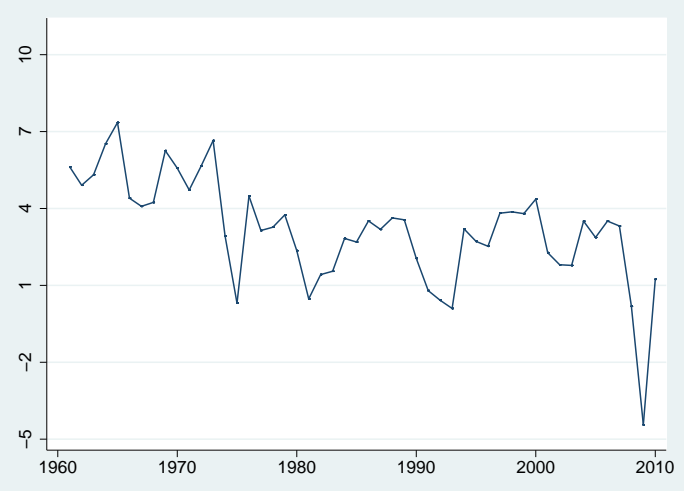

Avg. growth rate South \& Central America

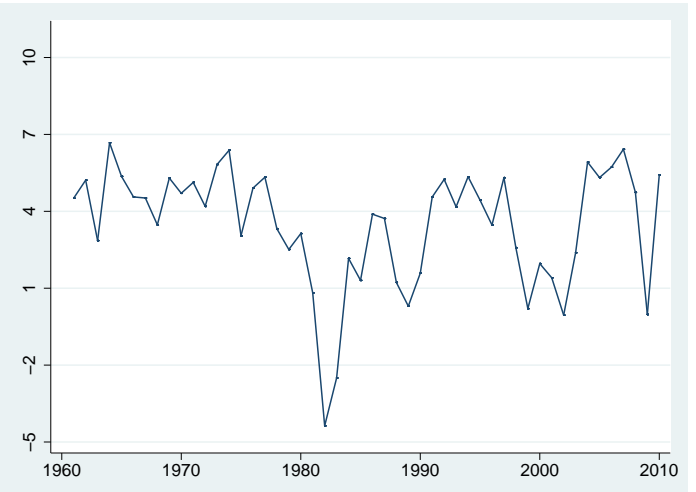

Notes: $\mathrm{x}$-axis $=$ year, $\mathrm{y}$-axis $=$ average growth rate $(g r)$.

Figure 2: Average growth rates over time 
to tame their business cycles since the mid 70s, whereas African nations continue to incur strongly volatile periods. Noteworthy is also a comparison between the richest nations, as cycles generally appear more prevalent in North America with the oil crisis in the early 70s standing out. Finally, the 2008 global financial crisis is especially visible in the Americas and Europe, as for the average European country volatility reached its highest level since the mid 60 s.

\section{Empirical Findings}

\subsection{OLS Results}

Table 3 displays results from the generic growth regression of equation 1, gradually adding explanatory variables. Column (1) starts with the most basic model, only using volatility and the growth rate of the previous year as regressors. Columns (2) and (3) add country fixed effects and country time trends, accounting for the individual characteristics of each country. Specification (4) adds government size, following Barro and Lee (1994), Barro (2001), and Afonso and Furceri (2010). Finally, (5) and (6) add the growth determinants used by Levine and Renelt (1992) and Mirestean and Tsangarides (2009).

As for the coefficient of interest, we find no evidence for the importance of volatility. The coefficient on $v o l$ is mostly positive, but insignificant in all specifications (although close to the ten percent significance level in the final specifications). Estimates for the effects of other control variables confirm prevailing conclusions in the literature. Investment, life expectancy, and openness to trade have positive and significant effects on growth, whereas income and inflation carry negative growth effects.

Were one to stop here, the conclusion would be that either the business cycle does not affect economic growth at all or that there exists a weak positive relationship. In fact, distinguishing by continents, population size, time frames, or OECD and non-OECD produces an insignificant coefficient for vol as well (results displayed in tables A.1 and A.2). However, a closer look reveals that including government size in column (4) changes the coefficient on volatility remarkably, suggesting potential problems of endogeneity. In fact, Durbin-Wu-Hausman (DWH) test statistics reveal that the regressions are problematic and government size is endogenous. The significance of the F-values, displayed at the bottom of each regression, indicates that OLS estimates are not consistent.

\section{2. $3 S L S$ Results}

Table 4 proceeds to results from estimating growth and government size simultaneously, displaying Ftests for the joint insignificance of the respective instruments under each regression. ${ }^{11}$ For lack of space, all

\footnotetext{
${ }^{11}$ Values of F-tests in all but one regression are substantially higher than ten, clearing the threshold level for weak instruments identified by Staiger and Stock (1997). Only in the subsamples of autocracies and anocracies, displayed in columns (3) and (4), does the value not exceed ten.
} 
Table 2: Countries by average volatility (vol) from $1961-2010$.

\begin{tabular}{|c|c|c|c|}
\hline Country & Avg. volatility & Country & Avg. volatility \\
\hline \multicolumn{2}{|l|}{ Africa } & \multicolumn{2}{|l|}{ Europe } \\
\hline South Africa & 0.039 & France & 0.018 \\
\hline Egypt, Arab Rep. & 0.061 & Norway & 0.020 \\
\hline Benin & 0.080 & Austria & 0.024 \\
\hline Burkina Faso & 0.092 & Belgium & 0.026 \\
\hline Senegal & 0.126 & Spain & 0.028 \\
\hline Ghana & 0.129 & Netherlands & 0.030 \\
\hline Central African Republic & 0.137 & Italy & 0.033 \\
\hline Botswana & 0.150 & Sweden & 0.034 \\
\hline Madagascar & 0.158 & United Kingdom & 0.035 \\
\hline Cote d'Ivoire & 0.173 & Denmark & 0.041 \\
\hline Zambia & 0.174 & Portugal & 0.072 \\
\hline Morocco & 0.182 & Greece & 0.073 \\
\hline Kenya & 0.182 & Finland & 0.073 \\
\hline Cameroon & 0.210 & Luxembourg & 0.091 \\
\hline Congo, Dem. Rep. & 0.232 & Iceland & 0.123 \\
\hline Congo, Rep. & 0.242 & Hungary & 0.282 \\
\hline Malawi & 0.246 & & \\
\hline Sudan & 0.249 & \multicolumn{2}{|l|}{ Oceania } \\
\hline Burundi & 0.272 & Australia & 0.025 \\
\hline Togo & 0.295 & Papua New Guinea & 0.149 \\
\hline Niger & 0.298 & Fiji & 0.176 \\
\hline Zimbabwe & 0.327 & \multicolumn{2}{|l|}{ North America } \\
\hline Mauritania & 0.335 & Canada & 0.032 \\
\hline Sierra Leone & 0.339 & United States & 0.038 \\
\hline Lesotho & 0.386 & Puerto Rico & 0.051 \\
\hline Nigeria & 0.414 & Honduras & 0.080 \\
\hline Algeria & 0.531 & Mexico & 0.095 \\
\hline Chad & 0.621 & Bermuda & 0.105 \\
\hline Gabon & 0.774 & Trinidad and Tobago & 0.112 \\
\hline Rwanda & 1.033 & Belize & 0.129 \\
\hline Seychelles & 1.947 & Panama & 0.132 \\
\hline Liberia & 3.112 & Dominican Republic & 0.238 \\
\hline \multirow{2}{*}{ Liberia } & & St. Vincent and the Grenadines & 0.353 \\
\hline & 0.031 & Bahamas, The & 0.371 \\
\hline Pakistan & 0.042 & \multicolumn{2}{|c|}{ South \& Central America } \\
\hline Japan & 0.060 & Guatemala & 0.031 \\
\hline Philippines & 0.065 & Colombia & 0.034 \\
\hline Nepal & 0.066 & Costa Rica & 0.083 \\
\hline India & 0.077 & Bolivia & 0.087 \\
\hline Israel & 0.093 & Ecuador & 0.087 \\
\hline Korea, Rep. & 0.096 & El Salvador & 0.090 \\
\hline Thailand & 0.097 & Brazil & 0.098 \\
\hline Malaysia & 0.099 & Paraguay & 0.109 \\
\hline Indonesia & 0.102 & Uruguay & 0.154 \\
\hline Bangladesh & 0.121 & Chile & 0.174 \\
\hline Singapore & 0.137 & Guyana & 0.190 \\
\hline Turkey & 0.143 & Peru & 0.199 \\
\hline China & 0.354 & Venezuela, RB & 0.240 \\
\hline Syrian Arab Republic & 0.543 & Nicaragua & 0.267 \\
\hline Oman & 1.772 & Argentina & 0.286 \\
\hline
\end{tabular}


Avg. volatility worldwide

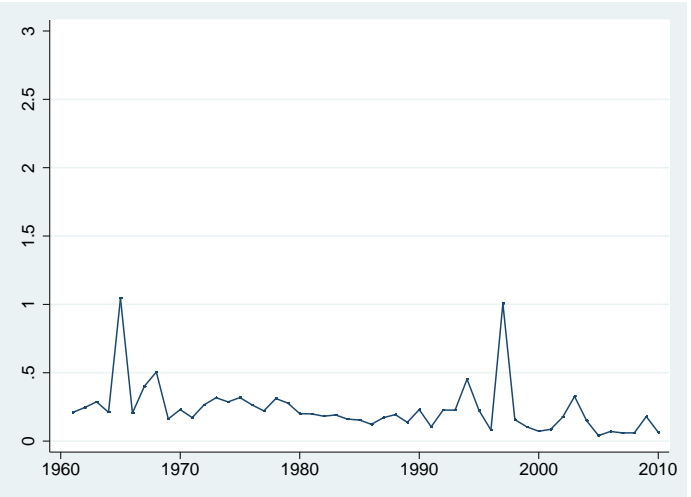

Avg. volatility

Asia \& Oceania

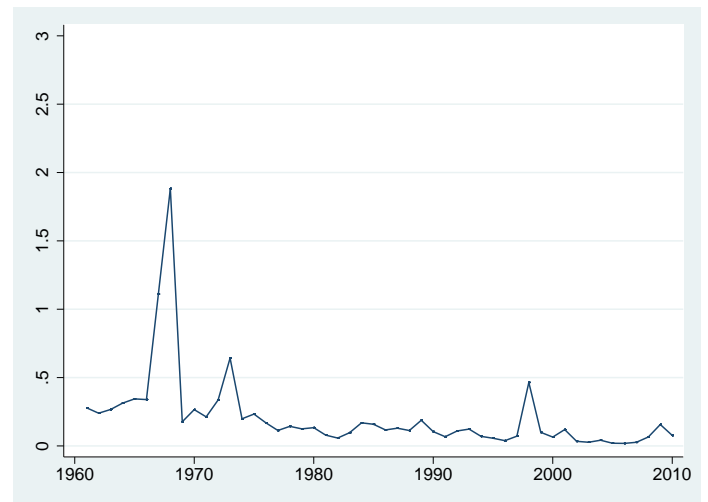

Avg. volatility

North America

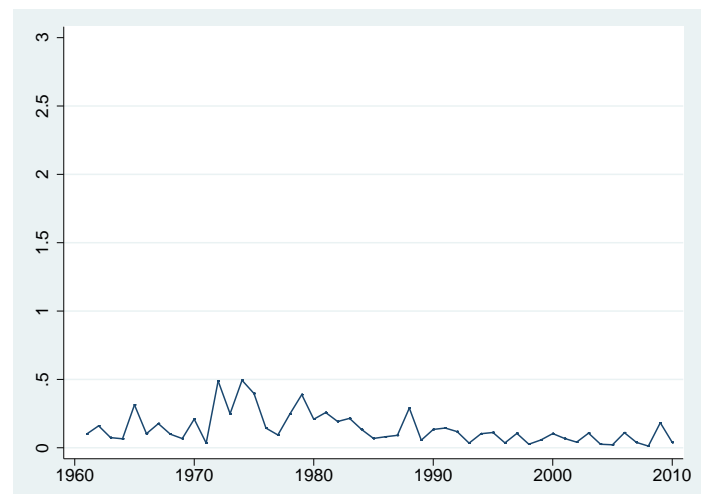

Avg. volatility Africa

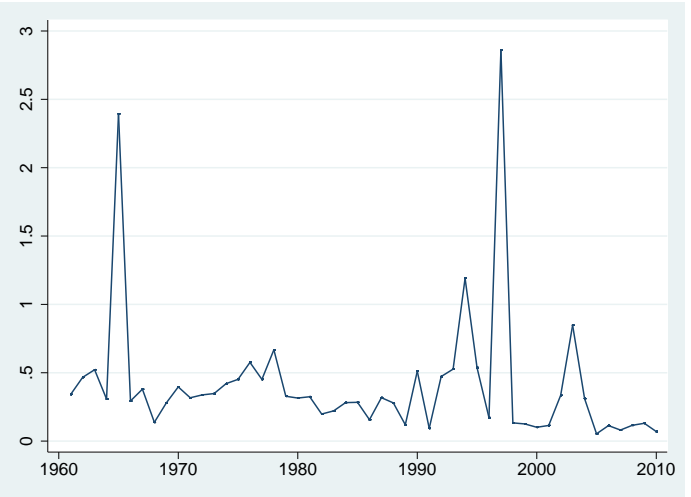

Avg. volatility

Europe

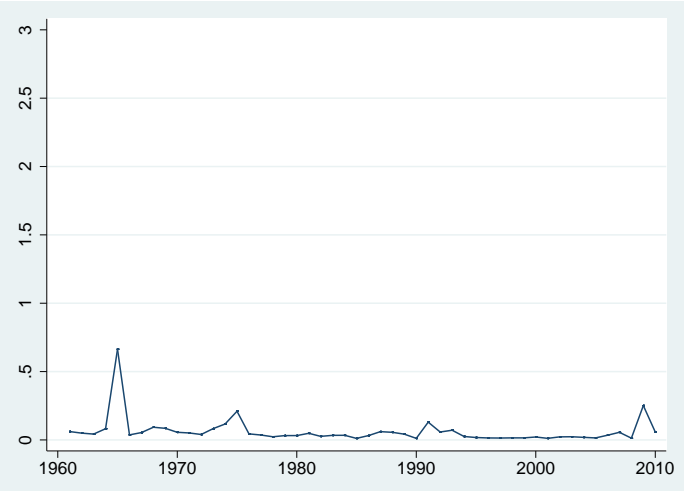

Avg. volatility South \& Central America

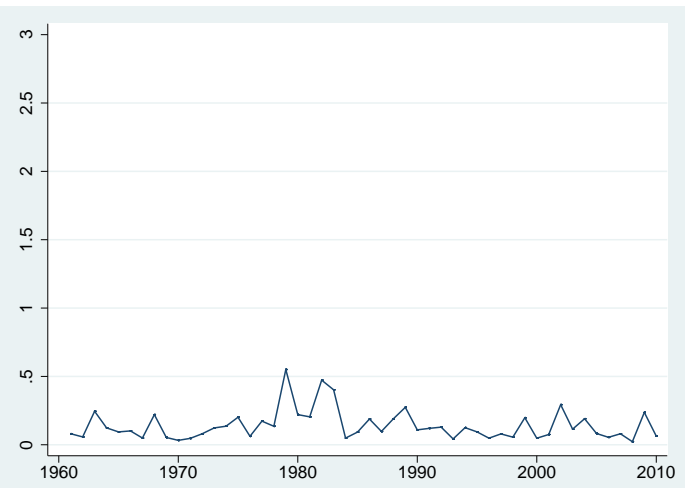

Notes: $\mathrm{x}$-axis $=$ year, $\mathrm{y}$-axis $=$ average volatility $(\mathrm{vol})$.

Figure 3: Average volatility over time 
Table 3: OLS results

\begin{tabular}{|c|c|c|c|c|c|c|}
\hline & (1) & $(2)$ & (3) & (4) & (5) & (6) \\
\hline \multicolumn{7}{|c|}{ Dependent variable: $g r_{i, t}$} \\
\hline $\operatorname{vol}_{i, t-1}$ & $\begin{array}{l}0.008 \\
(0.184)\end{array}$ & $\begin{array}{c}0.029 \\
(0.180)\end{array}$ & $\begin{array}{l}-0.003 \\
(0.181)\end{array}$ & $\begin{array}{c}0.585 \\
(0.370)\end{array}$ & $\begin{array}{c}0.516 \\
(0.361)\end{array}$ & $\begin{array}{c}0.586 \\
(0.389)\end{array}$ \\
\hline$g r_{i, t-1}$ & $\begin{array}{l}0.313^{* * *} \\
(0.042)\end{array}$ & $\begin{array}{c}0.263^{* * *} \\
(0.043)\end{array}$ & $\begin{array}{c}0.219^{* * *} \\
(0.045)\end{array}$ & $\begin{array}{c}0.173^{* * *} \\
(0.040)\end{array}$ & $\begin{array}{c}0.200^{* * *} \\
(0.031)\end{array}$ & $\begin{array}{c}0.192^{* * *} \\
(0.032)\end{array}$ \\
\hline $\operatorname{lngov}_{i, t}$ & & & & $\begin{array}{c}-1.514^{* *} \\
(0.645)\end{array}$ & $\begin{array}{c}2.678^{* * *} \\
(0.624)\end{array}$ & $\begin{array}{c}1.979^{* * *} \\
(0.592)\end{array}$ \\
\hline $\operatorname{lninv}_{i, t-1}$ & & & & & $\begin{array}{c}1.343^{* * *} \\
(0.432)\end{array}$ & $\begin{array}{l}0.966^{* *} \\
(0.435)\end{array}$ \\
\hline $\operatorname{lng} d p_{i, t-1}$ & & & & & $\begin{array}{c}-13.215^{* * *} \\
(1.593)\end{array}$ & $\begin{array}{c}-14.455^{* * *} \\
(1.722)\end{array}$ \\
\hline popgr $_{i, t-1}$ & & & & & $\begin{array}{c}3.333 \\
(4.546)\end{array}$ & $\begin{array}{c}0.950 \\
(3.829)\end{array}$ \\
\hline $\operatorname{lnlife} e_{i, t-1}$ & & & & & & $\begin{array}{c}15.820^{* * *} \\
(5.019)\end{array}$ \\
\hline $\operatorname{lnopen}_{i, t-1}$ & & & & & & $\begin{array}{c}2.230^{* * *} \\
(0.487)\end{array}$ \\
\hline $\operatorname{lninf} l_{i, t-1}$ & & & & & & $\begin{array}{c}-0.917^{* * *} \\
(0.314)\end{array}$ \\
\hline $\begin{array}{l}\text { Country } \\
\text { fixed effects }\end{array}$ & & yes & yes & yes & yes & yes \\
\hline $\begin{array}{l}\text { Country } \\
\text { time trend }\end{array}$ & & & yes & yes & yes & yes \\
\hline DWH-test $^{a}$ & & & & $62.40^{* * *}$ & $36.66^{* * *}$ & $43.59^{* * *}$ \\
\hline$N$ & 4,655 & 4,655 & 4,655 & 4,387 & 4,346 & 4,273 \\
\hline$R^{2}$ & 0.100 & 0.135 & 0.168 & 0.219 & 0.225 & 0.255 \\
\hline
\end{tabular}

Notes: Standard errors in parentheses. ${ }^{*} p<0.10,{ }^{* *} p<0.05,{ }^{* * *} p<0.01$. ${ }^{a}$ Testing for the endogeneity of government size, where the government size equation contains $\operatorname{lngov}_{i, t-1}, \operatorname{lnopen}_{i, t-1}, \operatorname{lng} d p_{i, t-1}, \operatorname{lnpop}_{i, t-1}$, country fixed effects, and country specific time trends. 
coefficients, which are not the main focus of this paper are referred to table A.3. ${ }^{12}$ The remaining growth coefficients show no surprises compared to table 3 and neither do the coefficients on the control variables predicting government size, compared to the prevailing conclusions in the corresponding literature. ${ }^{13}$

Columns (1) and (2) use the entire sample and we notice a remarkable difference relative to the single estimation framework above. Volatility is positive and highly significant in affecting growth directly, but also increases government size, which in turn lowers growth. Although the quantitative interpretation on the volatility coefficient in the growth regression is remarkably stable compared to the final single estimation in table 3, the accuracy of the 3SLS system is highly improved. In fact, the standard error shrinks to almost one fourth of its OLS counterpart. Thus, even though the magnitude of the indirect effect in the total sample is low compared to the direct channel, accounting for the indirect channel improves the statistical accuracy substantially.

As a next step, it is important to analyze the indirect mechanism in more detail. Especially the link between the citizens' ability to articulate their wishes in terms of public goods provision is an essential component here. Without the ability to engage in the political process, the citizens' options to respond to volatility are limited. Thus, the final columns of table 4 distinguish by political regime form.

Column (3) only considers countries, which at the time of observation are marked as autocracies or closed anocracies $(\mathrm{pol}<0)$. These regimes are defined by a lack of political participation for citizens or that citizens are subject to a ruling elite. The positive direct effect is strengthened with its magnitude increasing by about 50 percent. However, volatility does not seem to affect government size in autocracies. This result seems quite intuitive as the citizens' options to influence the provision and extent of public services is by definition limited in autocratic regimes.

These results are reversed in regimes, where citizens receive the opportunity to engage in the political process, displayed in column (4). Regimes with a positive pol score are denoted as open anocracies or democracies. We note a stark difference to autocracies, as the direct effect shrinks to almost one third of its initial magnitude and becomes insignificant. The indirect channel through government size on the other hand becomes important, as volatility raises the public sector, which in turn continues to lower growth. This suggests a shift in response to volatility shocks, depending on the political regime: In autocracies the positive direct effect dominates, whereas in democracies the negative indirect effect takes over, presumably operating through an insurance mechanism of the public sector.

\footnotetext{
${ }^{12}$ As an additional check, table A.4 only uses observations, for which information on the full set of variables is available. The qualitative interpretation remains the same, with only very minor changes in magnitudes. Thus, observations which are lost when including additional variables are not driving the results displayed in table 4 .

${ }^{13}$ Wagner's Law receives support as richer countries are associated with bigger governments. In addition, bigger populations seem to have smaller governments in relative terms, although this result is weaker - an artifact potentially due to low variation in population size from year to year (see Alesina and Wacziarg, 1998, who average over multiple years). Further, I find mixed evidence for the effect from openness to trade (a relationship heavily discussed since Rodrik, 1998).
} 
Table 4: 3SLS results

\begin{tabular}{|c|c|c|c|c|c|}
\hline & \multicolumn{2}{|c|}{ Full sample } & \multirow{2}{*}{$\begin{array}{c}\operatorname{pol}_{i, t-1}<0 \\
(3)\end{array}$} & \multirow{2}{*}{$\begin{array}{c}\operatorname{pol}_{i, t-1}>0 \\
(4)\end{array}$} & \multirow{2}{*}{$\begin{array}{l}\text { Full sample } \\
\qquad(5)\end{array}$} \\
\hline & (1) & $(2)$ & & & \\
\hline \multicolumn{6}{|c|}{ Dependent variable: $g r_{i, t}$} \\
\hline $\operatorname{vol}_{i, t-1}$ & $\begin{array}{c}0.587^{* * *} \\
(0.100)\end{array}$ & $\begin{array}{c}0.603^{* * *} \\
(0.100)\end{array}$ & $\begin{array}{c}0.897^{* * *} \\
(0.145)\end{array}$ & $\begin{array}{c}0.211 \\
(0.177)\end{array}$ & $\begin{array}{l}0.329^{* *} \\
(0.141)\end{array}$ \\
\hline $\operatorname{lngov}_{i, t}$ & $\begin{array}{c}-0.929^{* *} \\
(0.438)\end{array}$ & $\begin{array}{c}-1.236^{* * *} \\
(0.438)\end{array}$ & $\begin{array}{r}-1.623^{*} \\
(0.913)\end{array}$ & $\begin{array}{c}-1.590^{* *} \\
(0.630)\end{array}$ & $\begin{array}{c}-1.439^{* * *} \\
(0.454)\end{array}$ \\
\hline$g r_{i, t-1}$ & $\begin{array}{c}0.173^{* * *} \\
(0.015)\end{array}$ & $\begin{array}{c}0.169^{* * *} \\
(0.015)\end{array}$ & $\begin{array}{c}0.087^{* * *} \\
(0.024)\end{array}$ & $\begin{array}{c}0.280^{* * *} \\
(0.020)\end{array}$ & $\begin{array}{c}0.142^{* * *} \\
(0.016)\end{array}$ \\
\hline $\operatorname{vol}_{i, t-1} \times \operatorname{pol}_{i, t-1}$ & & & & & $\begin{array}{c}-0.060^{* * *} \\
(0.023)\end{array}$ \\
\hline $\operatorname{pol}_{i, t-1}$ & & & & & $\begin{array}{l}0.041^{*} \\
(0.022)\end{array}$ \\
\hline $\begin{array}{l}\text { Country fixed effects \& } \\
\text { time trends }\end{array}$ & yes & yes & yes & yes & yes \\
\hline Control sets ${ }^{a}$ & yes & yes & yes & yes & yes \\
\hline $\begin{array}{l}\text { F-test joint insignifi- } \\
\text { cance of } \mathrm{IVs}^{b}\end{array}$ & $26.29^{* * *}$ & $17.02^{* * *}$ & $4.23^{* * *}$ & $20.20^{* * *}$ & $13.86^{* * *}$ \\
\hline \multicolumn{6}{|c|}{ Dependent variable: $\operatorname{lngov}_{i, t}$} \\
\hline $\operatorname{vol}_{i, t-1}$ & $\begin{array}{l}0.006^{* *} \\
(0.003)\end{array}$ & $\begin{array}{l}0.006^{* *} \\
(0.003)\end{array}$ & $\begin{array}{l}-0.001 \\
(0.004)\end{array}$ & $\begin{array}{l}0.012^{* *} \\
(0.005)\end{array}$ & $\begin{array}{c}0.012^{* * *} \\
(0.004)\end{array}$ \\
\hline$g r_{i, t}$ & $\begin{array}{c}0.004^{* * *} \\
(0.001)\end{array}$ & $\begin{array}{c}0.013^{* * *} \\
(0.002)\end{array}$ & $\begin{array}{c}0.012^{* * *} \\
(0.003)\end{array}$ & $\begin{array}{c}0.006^{* * *} \\
(0.002)\end{array}$ & $\begin{array}{c}0.014^{* * *} \\
(0.002)\end{array}$ \\
\hline $\operatorname{lngov}_{i, t-1}$ & $\begin{array}{c}0.868^{* * *} \\
(0.008)\end{array}$ & $\begin{array}{c}0.795^{* * *} \\
(0.010)\end{array}$ & $\begin{array}{c}0.728^{* * *} \\
(0.017)\end{array}$ & $\begin{array}{c}0.735^{* * *} \\
(0.013)\end{array}$ & $\begin{array}{c}0.792^{* * *} \\
(0.010)\end{array}$ \\
\hline $\operatorname{vol}_{i, t-1} \times$ pol $_{i, t-1}$ & & & & & $\begin{array}{l}0.001^{* *} \\
(0.001)\end{array}$ \\
\hline $\operatorname{pol}_{i, t-1}$ & & & & & $\begin{array}{l}-0.001 \\
(0.001)\end{array}$ \\
\hline $\begin{array}{l}\text { Country fixed effects \& } \\
\text { time trends }\end{array}$ & yes & yes & yes & yes & yes \\
\hline Control set ${ }^{c}$ & & yes & yes & yes & yes \\
\hline $\begin{array}{l}\text { F-test joint insignifi- } \\
\text { cance of IVs }{ }^{d}\end{array}$ & $1,877.11^{* * *}$ & $571.41^{* * *}$ & $191.45^{* * *}$ & $220.03^{* * *}$ & $517.92^{* * *}$ \\
\hline$N$ & 4,266 & 4,266 & 1,651 & 2.536 & 3,974 \\
\hline
\end{tabular}

Notes: Standard errors in parentheses. ${ }^{*} p<0.10,{ }^{* *} p<0.05,{ }^{* * *} p<0.01$.

${ }^{a}$ Control variables from Levine and Renelt (1992) and Mirestean and Tsangarides (2009):

investment $\left(\operatorname{lninv} v_{i, t-1}\right)$, GDP $\left(l n g d p_{i, t-1}\right)$, population growth $\left(\right.$ popgr $\left._{i, t-1}\right)$, life expectancy $\left(\operatorname{lnlif}_{i, t-1}\right)$, openness to trade $\left(\operatorname{lnopen}_{i, t-1}\right)$, and inflation $\left(\operatorname{lninf} l_{i, t-1}\right)$.

${ }^{b}$ IVs are regressors exclusively used in the growth equation.

${ }^{c}$ Control set Shelton (2007): GDP $\left(\operatorname{lng} d p_{i, t-1}\right)$, trade openness $\left(\operatorname{lnopen}_{i, t-1}\right)$, and population size $\left(\operatorname{lnpop}_{i, t-1}\right)$.

${ }^{d}$ IVs are regressors exclusively used in the government size equation. 
One downfall of this analysis is the arbitrary distinction into positive and negative values of polity. Thus, column (5) uses the entire sample, including an interaction term between volatility and the polity score. We note that the interaction term is negative and significant in determining growth, but positive and significant in determining government size. Thus, as the democratic system rises, the direct effect of volatility on growth diminishes, but the indirect effect gains importance. ${ }^{14}$ Following this final and most complete specification, a one standard deviation of volatility is suggested to lower the growth rate of GDP by 0.57 percentage points in a country with a perfect polity score of $+10 .{ }^{15}$ On the other end of the spectrum, a totally autocratic regime (polity score of -10) would enjoy an increase in the rate of economic growth by as much as 1.74 percentage points.

\subsection{Development Over Time and Country Examples}

In fact, the results suggest a threshold level of a country's polity score of +5.4 , over which the net effect of volatility on growth becomes negative. ${ }^{16}$ Interestingly, the Polity $I V$ project's definition of democracy starts precisely at a score of +6 . As a reference point, Bangladesh and Ecuador received a score of +5 in the 2010 Polity report, whereas countries like Malaysia or Pakistan would be slightly above the threshold value with a score of +6 .

Figure 4 displays several sample countries, which incurred substantial switches in regime form since the 1960s. All graphs show how a one standard deviation of volatility would affect the rate of economic growth, according to the main results from table 4, column (5).

In Argentina, the collapse of the military government and the subsequent "New Democracy" pushed the country to polity scores over 5.4, which would then suggest detrimental consequences of volatility on growth. In Spain, a period of relatively high volatility in the early 70 s spurred growth, as the country received a polity score of -7 under the dictatorship of Franco. However, times of strong volatility in the late 80 s and early 90 s, as well as in 2009, should have had negative growth effects, as the country was considered a perfect democracy. Indeed, Spain's government size remained relatively stable in the early 70s (10.1 - 10.6 percent between 1970 and 1974), but jumped from 15.4 percent in 1986 to 18.8 percent in 1993. Severe changes in political regime form can be observed in numerous other countries, such as Brazil, Ghana, Portugal, or Thailand.

Figure 5 shows the amount of countries, which are suggested to have had positive net growth effects from volatility over time. In general, this number decreases especially since the 1980s, as countries moved towards democracies. Until then, about 70 of the 95 sample countries are suggested to have enjoyed

\footnotetext{
${ }^{14}$ Including an interaction term of government size with pol in the growth regression did not produce significant results. Thus, I do not find evidence that the negative effect of government size on growth varies by level of democracy.

${ }^{15}$ Calculation: $\Delta g r=1.87[0.329-10 \times 0.060-1.439(0.012+10 \times 0.001)]$.

${ }^{16}$ Calculation for the threshold level: $0.329-p o l \times 0.060-1.439 \times(0.012+p o l \times 0.001)=0$.
} 
Argentina

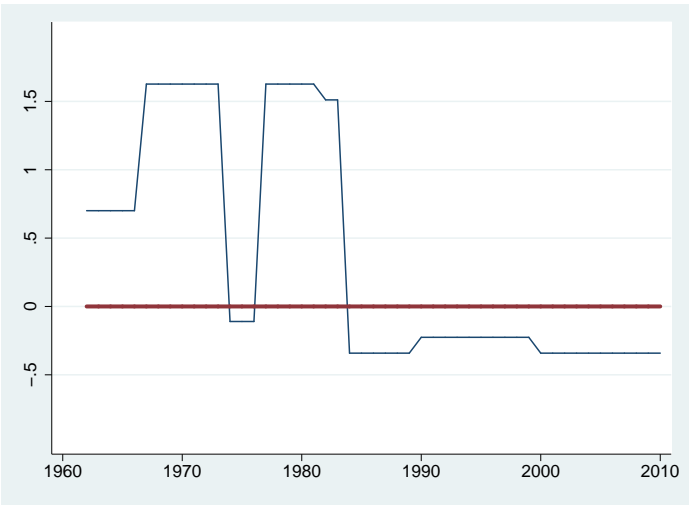

Ghana

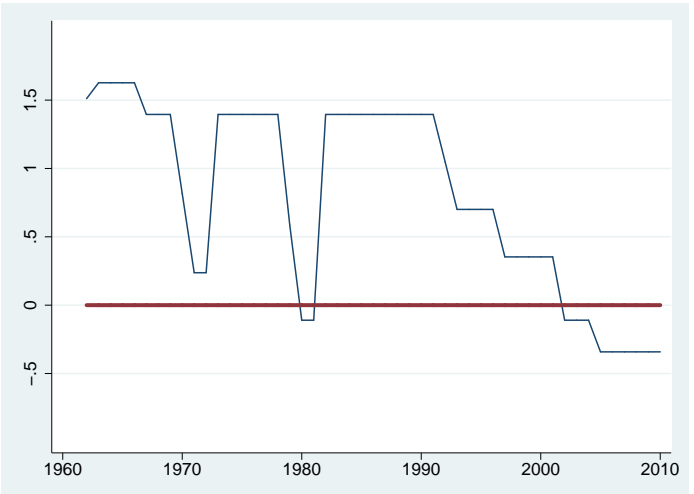

Spain

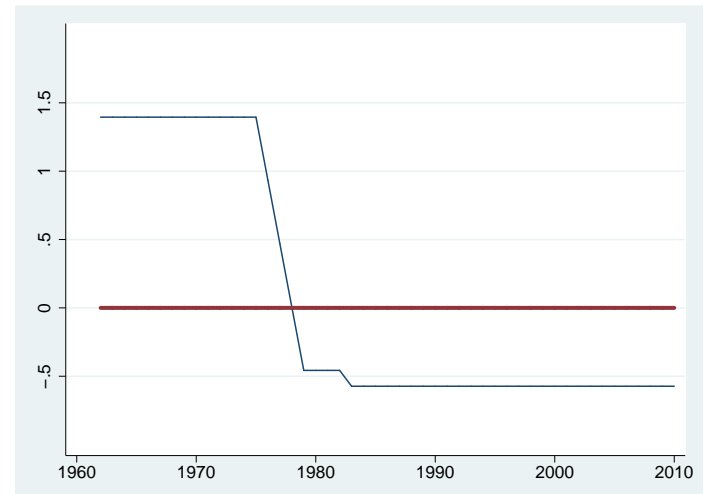

Brazil

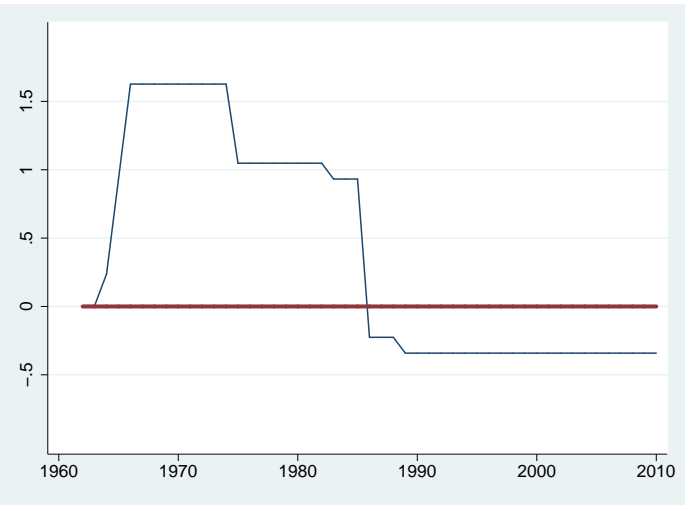

Portugal

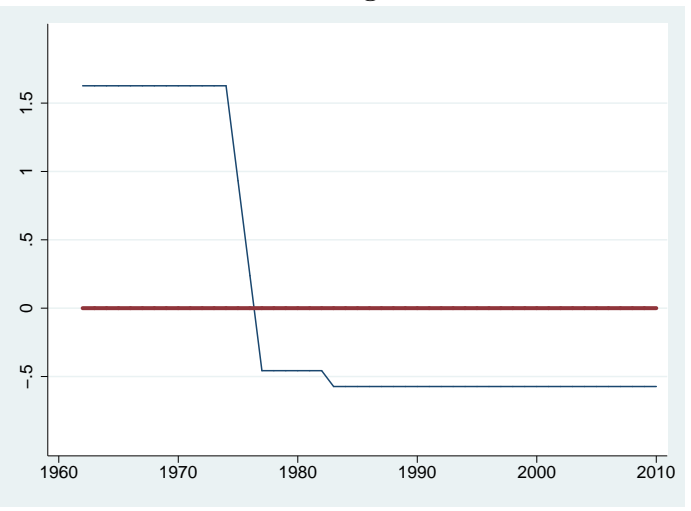

Thailand

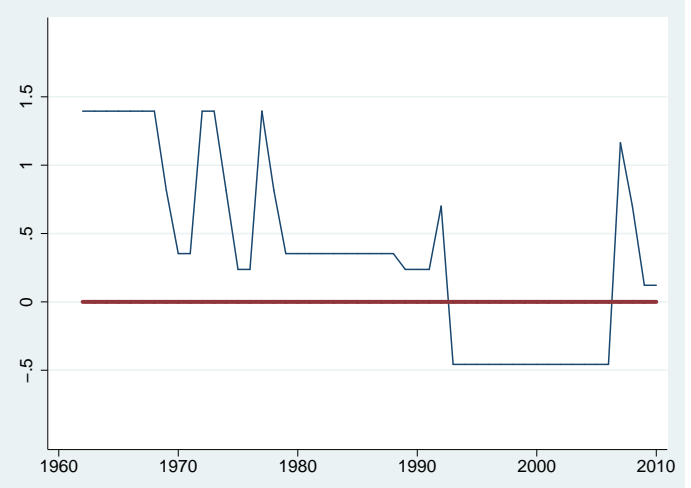

Notes: $\mathrm{x}$-axis $=$ year; $\mathrm{y}$-axis $=$ Suggested net effect of a one standard deviation increase of $v_{i, t-1}$ on economic growth in percentage points.

Figure 4: Net effects from volatility on growth 
positive net growth effects from volatility due to a lack of democratic institutions. In 2010 however, less than 40 countries would fall into this category. The remaining graphs show that this move towards democracy is not specific to selected regions, but rather a worldwide phenomenon.

\subsection{Robustness Checks}

This section presents several alternative specifications, addressing the method of detrending growth rates, the definition of government size, and the possibility of the political regime being sufficient to explain the results, i.e. the indirect effect being redundant. Table 5 displays the results of replicating the two main specifications (2) and (5) from table 4 for each robustness check. Finally, table 6 replicates the initial single regression results, this time including $p o l$ and its interaction term with volatility.

First, the benchmark value of $\lambda_{H P}=100$ for annual data has been subject to criticism in the econometrics literature, where most notably Ravn and Uhlig (2002) suggest a value of $\lambda_{H P}=6.25$. Columns (1) and (2) in table 5 show the results when detrending growth rates with $\lambda_{H P}=6.25$. The implications of the main results are confirmed, as we observe both a positive direct and a negative indirect effect, where the polity score plays the same key role as before: Democracies tend to have negative net effects. Even though signs and significance levels mostly confirm the earlier findings, magnitudes are smaller, potentially owed to the fact that a lower $\lambda_{H P}$ translates to a smaller penalty for variations in the growth rate, i.e. the trend is given more flexibility.

Second, there exists a general criticism of the HP filter: The end of sample problem (Watson, 2007). Specifically, towards the beginning (the end) of a sample detrending can lose accuracy, as reference points in the past (the future) are missing. With a balanced sample of 50 observations per country, specifications (3) and (4) in table 5 display the main results after cutting off the first and final five years of the sample. This means that the volatility term is still estimated using the entire 50 years per country, but only the 40 years in the middle are used for regressions. A look at the results reveals no change in significance levels and only minor deviations in terms of magnitudes.

Third, columns (5) and (6) provide alternative results when using the Baxter-King (BK) filter to detrend growth rates (Baxter and King, 1999). These specifications serve as a check on whether the main results could be driven by any particular characteristic of the HP filter. We notice that significance levels are generally in line with the main results and the same pattern can be observed: There exists a positive direct and a negative indirect effect of volatility on growth. Once again, democracies tend to weaken the direct effect. However, in this case the negative indirect effect does not seem to be altered significantly by the pol score, although we observe the predicted sign.

Specifications (7) and (8) check whether the results are robust to using shares of government spending and investment in GDP. In the main estimations, I use the logarithm of total government spending and 
Worldwide (95 countries)

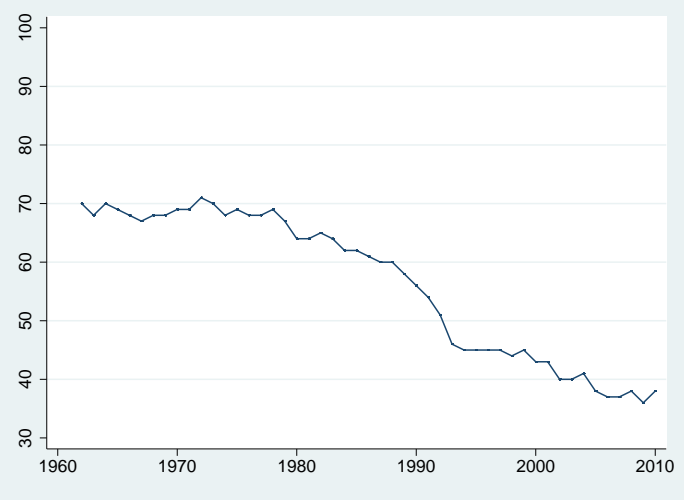

Asia (17 countries)

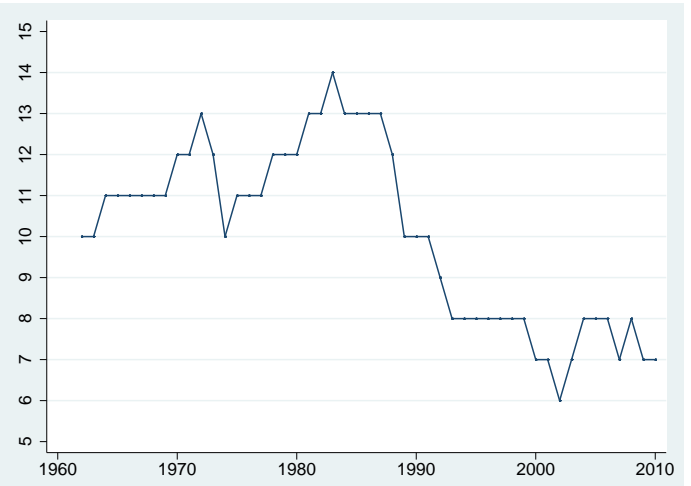

North America (12 countries)

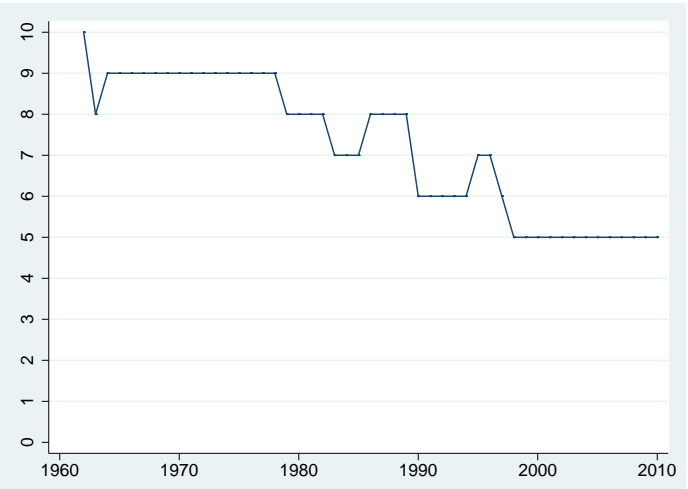

Notes: $\mathrm{x}$-axis $=$ year; $\mathrm{y}$-axis $=\#$ of countries
Africa (32 countries)

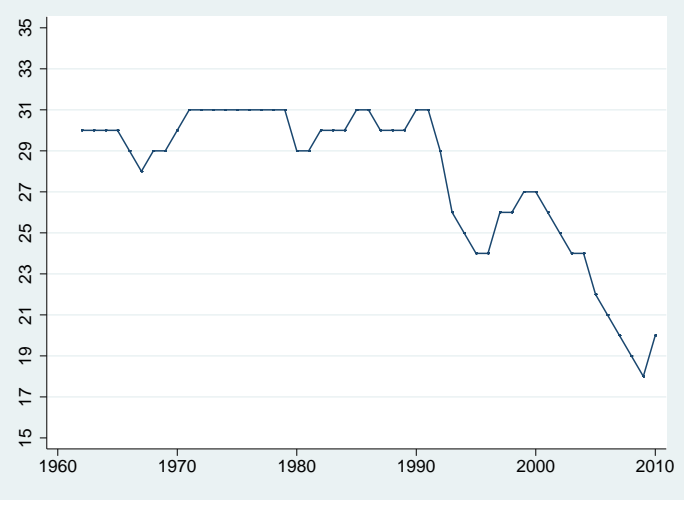

Europe (16 countries)

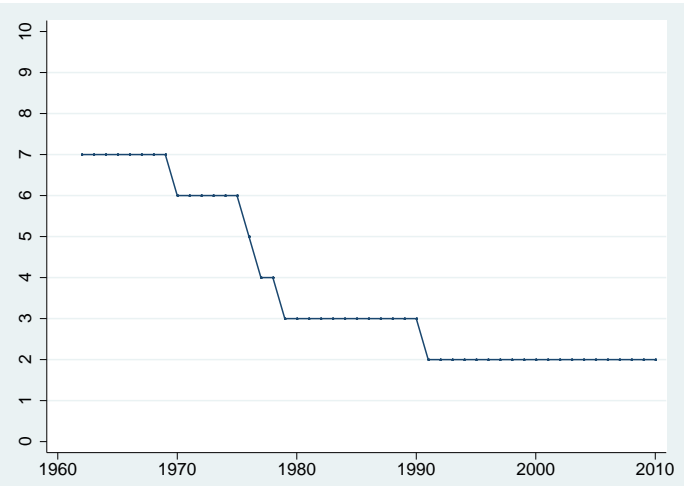

South \& Central America (15 countries)

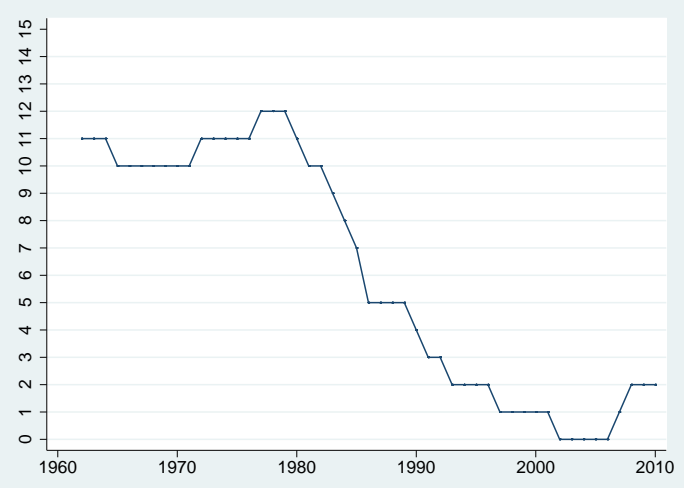

Figure 5: Amount of countries with predicted positive net growth effect from volatility over time. 
Table 5: Robustness checks

\begin{tabular}{|c|c|c|c|c|c|c|c|c|}
\hline & \multirow{2}{*}{\multicolumn{2}{|c|}{$\begin{array}{l}\operatorname{vol}_{\lambda_{H P}}=6.25 \\
(1)\end{array}$}} & \multicolumn{2}{|c|}{$1965-2005$} & \multicolumn{2}{|c|}{$v l_{B K}{ }^{a}$} & \multicolumn{2}{|c|}{ Using shares } \\
\hline & & & (3) & (4) & (5) & (6) & & (8) \\
\hline \multicolumn{9}{|c|}{ Dependent variable: $g r_{i, t}$} \\
\hline $\operatorname{vol}_{i, t-1}$ & $\begin{array}{l}0.008^{* * *} \\
(0.001)\end{array}$ & $\begin{array}{c}0.003 \\
(0.002)\end{array}$ & $\begin{array}{c}0.725^{* * *} \\
(0.108)\end{array}$ & $\begin{array}{l}0.375^{* *} \\
(0.157)\end{array}$ & $\begin{array}{c}0.848^{* * *} \\
(0.133)\end{array}$ & $\begin{array}{l}0.192 \\
(0.214)\end{array}$ & $\begin{array}{c}0.572^{* * *} \\
(0.078)\end{array}$ & $\begin{array}{c}0.281^{* *} \\
(0.139)\end{array}$ \\
\hline $\operatorname{lngov}_{i, t}$ & $\begin{array}{l}-1.261^{* * *} \\
(0.438)\end{array}$ & $\begin{array}{c}-1.484^{* * *} \\
(0.455)\end{array}$ & $\begin{array}{c}-2.446^{* * *} \\
(0.533)\end{array}$ & $\begin{array}{c}-2.694^{* * *} \\
(0.551)\end{array}$ & $\begin{array}{c}-1.627^{* * *} \\
(0.469)\end{array}$ & $\begin{array}{c}-1.885^{* * *} \\
(0.485)\end{array}$ & $\begin{array}{c}-0.111^{* * *} \\
(0.029)\end{array}$ & $\begin{array}{c}-0.122^{* * *} \\
(0.029)\end{array}$ \\
\hline$g r_{i, t-1}$ & $\begin{array}{l}0.167^{* * *} \\
(0.015)\end{array}$ & $\begin{array}{c}0.140^{* * *} \\
(0.016)\end{array}$ & $\begin{array}{c}0.181^{* * *} \\
(0.017)\end{array}$ & $\begin{array}{c}0.168^{* * *} \\
(0.017)\end{array}$ & $\begin{array}{c}0.190^{* * *} \\
(0.016)\end{array}$ & $\begin{array}{c}0.174^{* * *} \\
(0.016)\end{array}$ & $\begin{array}{c}0.174^{* * *} \\
(0.015)\end{array}$ & $\begin{array}{c}0.146^{* * *} \\
(0.016)\end{array}$ \\
\hline $\operatorname{vol}_{i, t-1} \times \operatorname{pol}_{i, t-1}$ & & $\begin{array}{c}-0.001^{* * *} \\
(0.000)\end{array}$ & & $\begin{array}{c}-0.001^{* * *} \\
(0.000)\end{array}$ & & $\begin{array}{c}-0.138^{* * *} \\
(0.034)\end{array}$ & & $\begin{array}{r}-0.045^{* *} \\
(0.018)\end{array}$ \\
\hline pol $_{i, t-1}$ & & $\begin{array}{l}0.043^{* *} \\
(0.022)\end{array}$ & & $\begin{array}{c}0.053^{* *} \\
(0.025)\end{array}$ & & $\begin{array}{l}0.054^{* *} \\
(0.023)\end{array}$ & & $\begin{array}{c}0.032 \\
(0.022)\end{array}$ \\
\hline $\begin{array}{l}\text { Country fixed effects } \\
\& \text { time trends }\end{array}$ & yes & yes & yes & yes & yes & yes & yes & yes \\
\hline Control sets ${ }^{b}$ & yes & yes & yes & yes & yes & yes & yes & yes \\
\hline \multicolumn{9}{|c|}{ Dependent variable: $\operatorname{lngov}_{i, t}$} \\
\hline $\operatorname{vol}_{i, t-1}$ & $\begin{array}{l}0.000^{*} \\
(0.000)\end{array}$ & $\begin{array}{l}0.000^{* *} \\
(0.000)\end{array}$ & $\begin{array}{l}0.006^{* *} \\
(0.003)\end{array}$ & $\begin{array}{c}0.015^{* * *} \\
(0.004)\end{array}$ & $\begin{array}{c}0.004 \\
(0.004)\end{array}$ & $\begin{array}{l}0.011^{*} \\
(0.006)\end{array}$ & $\begin{array}{l}-0.050 \\
(0.033)\end{array}$ & $\begin{array}{c}0.064 \\
(0.055)\end{array}$ \\
\hline$g r_{i, t}$ & $\begin{array}{l}0.012^{* * *} \\
(0.002)\end{array}$ & $\begin{array}{c}0.014^{* * *} \\
(0.002)\end{array}$ & $\begin{array}{c}0.014^{* * *} \\
(0.002)\end{array}$ & $\begin{array}{c}0.015^{* * *} \\
(0.002)\end{array}$ & $\begin{array}{c}0.012^{* * *} \\
(0.002)\end{array}$ & $\begin{array}{c}0.014^{* * *} \\
(0.002)\end{array}$ & $\begin{array}{l}-0.021 \\
(0.024)\end{array}$ & $\begin{array}{l}0.008 \\
(0.028)\end{array}$ \\
\hline $\operatorname{lngov}_{i, t-1}$ & $\begin{array}{l}0.794^{* * *} \\
(0.010)\end{array}$ & $\begin{array}{c}0.791^{* * *} \\
(0.010)\end{array}$ & $\begin{array}{c}0.781^{* * *} \\
(0.012)\end{array}$ & $\begin{array}{c}0.781^{* * *} \\
(0.012)\end{array}$ & $\begin{array}{c}0.804^{* * *} \\
(0.010)\end{array}$ & $\begin{array}{c}0.802^{* * *} \\
(0.011)\end{array}$ & $\begin{array}{c}0.794^{* * *} \\
(0.009)\end{array}$ & $\begin{array}{c}0.795^{* * *} \\
(0.010)\end{array}$ \\
\hline $\operatorname{vol}_{i, t-1} \times \operatorname{pol}_{i, t-1}$ & & $\begin{array}{c}0.000 \\
(0.000)\end{array}$ & & $\begin{array}{c}0.000^{* * *} \\
(0.000)\end{array}$ & & $\begin{array}{c}0.001 \\
(0.001)\end{array}$ & & $\begin{array}{c}0.021^{* * *} \\
(0.008)\end{array}$ \\
\hline pol $_{i, t-1}$ & & $\begin{array}{l}-0.001 \\
(0.001)\end{array}$ & & $\begin{array}{c}-0.001^{*} \\
(0.001)\end{array}$ & & $\begin{array}{l}-0.001 \\
(0.001)\end{array}$ & & $\begin{array}{r}-0.016^{*} \\
(0.009)\end{array}$ \\
\hline $\begin{array}{l}\text { Country fixed effects } \\
\& \text { time trends }\end{array}$ & yes & yes & yes & yes & yes & yes & yes & yes \\
\hline Control set ${ }^{c}$ & yes & yes & yes & yes & yes & yes & yes & yes \\
\hline$N$ & 4,266 & 3,974 & 3,531 & 3,314 & 3,874 & 3,628 & 4,306 & 4,009 \\
\hline
\end{tabular}

Notes: Standard errors in parentheses. ${ }^{*} p<0.10,{ }^{* *} p<0.05,{ }^{* * *} p<0.01$.

${ }^{a}$ Baxter-King filter applied to detrend growth rates.

${ }^{b}$ Control variables from Levine and Renelt (1992) and Mirestean and Tsangarides (2009):

Investment $\left(\operatorname{lninv} v_{i, t-1}\right)$, GDP $\left(\operatorname{lng} d p_{i, t-1}\right)$, population growth $\left(\right.$ popgr $\left._{i, t-1}\right)$, life expectancy $\left(\operatorname{lnlife} e_{i, t-1}\right)$,

openness to trade $\left(\operatorname{lnopen}_{i, t-1}\right)$, and inflation $\left(\operatorname{lnin} f l_{i, t-1}\right)$

${ }^{c}$ Control variables from Shelton (2007): GDP $\left(\operatorname{lng} d p_{i, t-1}\right)$, openness to trade $\left(\operatorname{lnopen}_{i, t-1}\right)$,

and population size $\left(\operatorname{lnpop}_{i, t-1}\right)$. 
total investment. In these specifications, the direct effect remains positive and significant, yet the indirect effect turns negative and insignificant in column (7). However, including the interaction with pol in column (8) recovers the main results. Notice that switching to shares changes the numerical interpretation of the coefficients associated with government size.

Table 6: OLS results, including $p o l_{i, t-1}$ and interaction term between $v l_{i, t-1}$ and $p l_{i, t-1}$

\begin{tabular}{|c|c|c|c|c|c|c|}
\hline & (1) & $(2)$ & $(3)$ & $(4)$ & $(5)$ & $(6)$ \\
\hline \multicolumn{7}{|c|}{ Dependent variable: $g r_{i, t}$} \\
\hline $\operatorname{vol}_{i, t-1}$ & $\begin{array}{l}0.021 \\
(0.104)\end{array}$ & $\begin{array}{c}0.071 \\
(0.103)\end{array}$ & $\begin{array}{c}0.056 \\
(0.110)\end{array}$ & $\begin{array}{c}0.406 \\
(0.397)\end{array}$ & $\begin{array}{c}0.320 \\
(0.361)\end{array}$ & $\begin{array}{c}0.343 \\
(0.405)\end{array}$ \\
\hline$g r_{i, t-1}$ & $\begin{array}{l}0.313^{* * *} \\
(0.040)\end{array}$ & $\begin{array}{c}0.262^{* * *} \\
(0.041)\end{array}$ & $\begin{array}{c}0.217^{* * *} \\
(0.043)\end{array}$ & $\begin{array}{c}0.156^{* * *} \\
(0.038)\end{array}$ & $\begin{array}{c}0.183^{* * *} \\
(0.033)\end{array}$ & $\begin{array}{c}0.169^{* * *} \\
(0.034)\end{array}$ \\
\hline $\operatorname{lngov}_{i, t}$ & & & & $\begin{array}{c}-1.672^{* *} \\
(0.688)\end{array}$ & $\begin{array}{c}2.537^{* * *} \\
(0.646)\end{array}$ & $\begin{array}{c}1.871^{* * *} \\
(0.610)\end{array}$ \\
\hline $\operatorname{vol}_{i, t-1} \times \operatorname{pol}_{i, t-1}$ & $\begin{array}{l}-0.079 \\
(0.060)\end{array}$ & $\begin{array}{c}-0.074 \\
(0.060)\end{array}$ & $\begin{array}{c}-0.071 \\
(0.059)\end{array}$ & $\begin{array}{l}-0.029 \\
(0.068)\end{array}$ & $\begin{array}{c}-0.041 \\
(0.058)\end{array}$ & $\begin{array}{l}-0.052 \\
(0.063)\end{array}$ \\
\hline pol $_{i, t-1}$ & $\begin{array}{l}-0.014 \\
(0.014)\end{array}$ & $\begin{array}{c}-0.001 \\
(0.019)\end{array}$ & $\begin{array}{l}0.052^{* *} \\
(0.026)\end{array}$ & $\begin{array}{c}0.034 \\
(0.026)\end{array}$ & $\begin{array}{c}0.023 \\
(0.024)\end{array}$ & $\begin{array}{l}0.044^{*} \\
(0.026)\end{array}$ \\
\hline Country fixed effects & & yes & yes & yes & yes & yes \\
\hline Country time trend & & & yes & yes & yes & yes \\
\hline Control set $1^{a}$ & & & & & yes & yes \\
\hline Control set $2^{b}$ & & & & & & yes \\
\hline$N$ & 4,192 & 4,192 & 4,192 & 4,050 & 4,014 & 3,980 \\
\hline$R^{2}$ & 0.129 & 0.165 & 0.194 & 0.215 & 0.249 & 0.271 \\
\hline
\end{tabular}

Notes: Standard errors in parentheses. ${ }^{*} p<0.10,{ }^{* *} p<0.05,{ }^{* * *} p<0.01$.

${ }^{a}$ Variables from Levine and Renelt (1992): Investment (lninv $\left.{ }_{i, t-1}\right)$, GDP (lngdp $\left.p_{i, t-1}\right)$, and population growth $\left(\right.$ popgr $\left._{i, t-1}\right)$.

${ }^{b}$ Control set Mirestean and Tsangarides (2009): GDP $\left(\operatorname{lng} d p_{i, t-1}\right)$,

life expectancy $\left(\operatorname{lnlife}_{i, t-1}\right)$, population growth $\left(\right.$ popgr $\left._{i, t-1}\right)$,

openness to trade $\left(\operatorname{lnopen}_{i, t-1}\right)$, and inflation $\left(\operatorname{lninf} l_{i, t-1}\right)$.

Finally, the results presented in this paper emphasize the importance of accounting for both the indirect effect and the political regime form. So far, it is not clear whether distinguishing by regime form alone might be able to explain this relationship. Thus, table 6 replicates the basic OLS table 3, this time including pol and its interaction term with volatility. If the indirect channel did not matter, 
then we should be able to observe similar results to the 3SLS estimations. However, these results are as inconclusive as before, showing that the indirect effect needs to be accounted for in order to explain the relationship between volatility and growth.

Overall, these robustness checks further strengthen the main findings. It does not seem likely that the results are driven by any particularities of the HP filter, the measurement of government size, or a simple distinction along the lines of regime form.

\section{Conclusion}

This paper analyzes the relationship between business cycles and economic growth in a new light, suggesting both a positive direct and a negative indirect effect from volatile growth rates on growth. A positive direct effect has previously been proposed by several theories (e.g., creative destruction or precautionary savings), but the paper's main contribution lies in revealing and accounting for the indirect channel. As public services act as an insurance mechanism in volatile times, volatility also increases the size of the public sector (after Rodrik, 1998). A bigger government can in turn lower growth in the short run. The paper shows that the importance of business cycles for economic growth could be dismissed if this indirect channel is not accounted for.

Whether the positive or the negative effect on growth dominates depends on a country's form of government. In autocratic regimes, the indirect channel is shut down, as people do not have the political power to determine their desired level of public services. The more democratic a country, the more likely it is that volatility carries negative net growth effects. Empirical estimates suggest that a one standard deviation of growth rate volatility may lower growth by as much as 0.57 percentage points in a perfect democracy. In a total autocracy however, a one standard deviation can raise growth by up to 1.74 percentage points. The main results suggest a threshold level of about +5.4 on the polity scale, although one should of course keep in mind possible data limitations.

In general, these findings strengthen the argument that business cycles do matter in the growth context. The implementation of policies aimed at limiting or unleashing volatility should keep in mind both the size of the public sector and the country's regime form. Governments could play a key role in the net relationship between business cycles and economic growth.

\section{Acknowledgements}

I am thankful to Alejandra Montoya Agudelo for excellent research assistance. I am also grateful to Jean Imbs, Alex Nikolsko-Rzhevskyy, Andrés Ramírez Hassan, William T. Smith, Theodore Breton, and participants of the DEGIT XVIII conference for fruitful discussions and helpful comments. All remaining errors are my own. 


\section{References}

Acemoglu, D., Johnson, S., Robinson, J., Thaicharoen, Y., 2003. Institutional causes, macroeconomic symptoms: Volatility, crises and growth. Journal of Monetary Economics 50, 49-123.

Afonso, A., Furceri, D., 2010. Government size, composition, volatility and economic growth. European Journal of Political Economy 26, 517-532.

Aghion, P., Angeletos, G.M., Banerjee, A., Manova, K., 2010. Volatility and growth: Credit constraints and the composition of investment. Journal of Monetary Economics 57, 246-265.

Aghion, P., Saint-Paul, G., 1998. Virtues of bad times interaction between productivity growth and economic fluctuations. Macroeconomic Dynamics 2, 322-344.

Alesina, A., Wacziarg, R., 1998. Openness, country size and government. Journal of Public Economics 69, 305-321.

Backus, D., Kehoe, P., 1992. International evidence on the historical properties of business cycles. American Economic Review , 864-888.

Badinger, H., 2010. Output volatility and economic growth. Economics Letters 106, 15-18.

Barro, R.J., 2001. Human capital and growth. American Economic Review 91, 12-17.

Barro, R.J., Lee, J.W., 1994. Sources of economic growth, in: Carnegie-Rochester conference series on public policy, Elsevier. pp. $1-46$.

Baum, C.F., 2006. Time series filtering techniques in Stata. Technical Report. Stata Users Group.

Baxter, M., King, R.G., 1999. Measuring business cycles: Approximate band-pass filters for economic time series. Review of Economics and Statistics 81, 575-593.

Brock, W.A., Durlauf, S.N., 2001. What have we learned from a decade of empirical research on growth? Growth empirics and reality. The World Bank Economic Review 15, 229-272.

Canton, E., 2002. Business cycles in a two-sector model of endogenous growth. Economic Theory 19, 477-492.

Caporale, T., McKiernan, B., 1998. The Fischer Black hypothesis: Some time-series evidence. Southern Economic Journal $64,765-771$.

Davidson, R., MacKinnon, J.G., 2001. Estimation and inference in econometrics. OUP Catalogue .

Dawson, J.W., Stephenson, E.F., 1997. The link between volatility and growth: Evidence from the States. Economics Letters 55, 365-369.

Devereux, M.B., Smith, G.W., 1994. International risk sharing and economic growth. International Economic Review 35, $535-50$.

Döpke, J., 2004. How robust is the empirical link between business-cycle volatility and long-run growth in OECD countries? International Review of Applied Economics 18, 103-121.

Durlauf, S., Johnson, P., Temple, J., 2005. Growth econometrics. Handbook of Economic Growth 1, $555-677$.

Henderson, D.J., Papageorgiou, C., Parmeter, C.F., 2013. Who benefits from financial development? New methods, new evidence. European Economic Review 63, 47-67.

Imbs, J., 2002. Why the link between volatility and growth is both positive and negative. CEPR discussion paper .

Imbs, J., 2007. Growth and volatility. Journal of Monetary Economics 54, 1848-1862.

Jetter, M., Nikolsko-Rzhevskyy, A., Smith, W.T., 2013. The effects of wage volatility on growth. Journal of Macroeconomics 37, 93-109.

Klomp, J., de Haan, J., 2009. Political institutions and economic volatility. European Journal of Political Economy 25, $311-326$.

Koren, M., Tenreyro, S., 2007. Volatility and development. The Quarterly Journal of Economics 122, $243-287$.

Kowal, P., 2005. Matlab implementation of commonly used filters. Computer Programs . 
Levine, R., Renelt, D., 1992. A sensitivity analysis of cross-country growth regressions. American Economic Review 82, $942-963$.

Martin, P., Ann Rogers, C., 2000. Long-term growth and short-term economic instability. European Economic Review 44, 359-381.

Masanjala, W.H., Papageorgiou, C., 2008. Rough and lonely road to prosperity: A reexamination of the sources of growth in Africa using Bayesian model averaging. Journal of Applied Econometrics 23, 671-682.

Mills, T.C., 2000. Business cycle volatility and economic growth: A reassessment. Journal of Post Keynesian Economics $23,107-116$.

Mirestean, A., Tsangarides, C., 2009. Growth Determinants Revisited. volume 9. International Monetary Fund.

Mirman, L.J., 1971. Uncertainty and optimal consumption decisions. Econometrica 39, 179-85.

Oikawa, K., 2010. Uncertainty-driven growth. Journal of Economic Dynamics and Control 34, 897-912.

Peacock, A., Scott, A., 2000. The curious attraction of Wagner's law. Public Choice 102, 1-17.

Philippe, A., Peter, H., 1992. A model of growth through creative destruction. Econometrica 60, 323-351.

Posch, O., Wälde, K., 2011. On the link between volatility and growth. Journal of Economic Growth 16, $285-308$.

Ramey, G., Ramey, V.A., 1995. Cross-country evidence on the link between volatility and growth. American Economic Review 85, 1138-1151.

Ravn, M.O., Uhlig, H., 2002. On adjusting the Hodrick-Prescott filter for the frequency of observations. Review of Economics and Statistics 84, 371-376.

Reinhart, C.M., Rogoff, K.S., 2010. Growth in a time of debt. American Economic Review 100, 573-578.

Robert, H., Prescott, E., 1997. Post-war US business cycles: An empirical investigation. Journal of Money, Credit and Banking 29, 1-16.

Rodrik, D., 1998. Why do more open economies have bigger governments? Journal of Political Economy 106, 997-1032.

Sáenz, E., Sabaté, M., Gadea, M.D., 2013. Trade openness and public expenditure. The Spanish case, 1960-2000. Public Choice 154, 173-195.

Saint-Paul, G., 1993. Productivity growth and the structure of the business cycle. European Economic Review 37, 861-883. Schumpeter, J.A., Fels, R., 1939. Business cycles. volume 1. Cambridge Univ Press.

Shelton, C., 2007. The size and composition of government expenditure. Journal of Public Economics 91, 2230-2260.

Solow, R.M., 1997. Is there a core of usable macroeconomics we should all believe in? American Economic Review 87, $230-232$.

Staiger, D., Stock, J.H., 1997. Instrumental variables regression with weak instruments. Econometrica 65, 557-586.

Temple, J., 1999. The new growth evidence. Journal of Economic Literature 37, 112-156.

Wang, P.f., Wen, Y., 2011. Volatility, growth, and welfare. Journal of Economic Dynamics and Control 35, $1696-1709$.

Watson, M., 2007. How accurate are real-time estimates of output trends and gaps? FRB Richmond Economic Quarterly 93, 143-161. 


\section{Appendix}

Table A.1: Main OLS regressions (table 3, column 6) by continents.

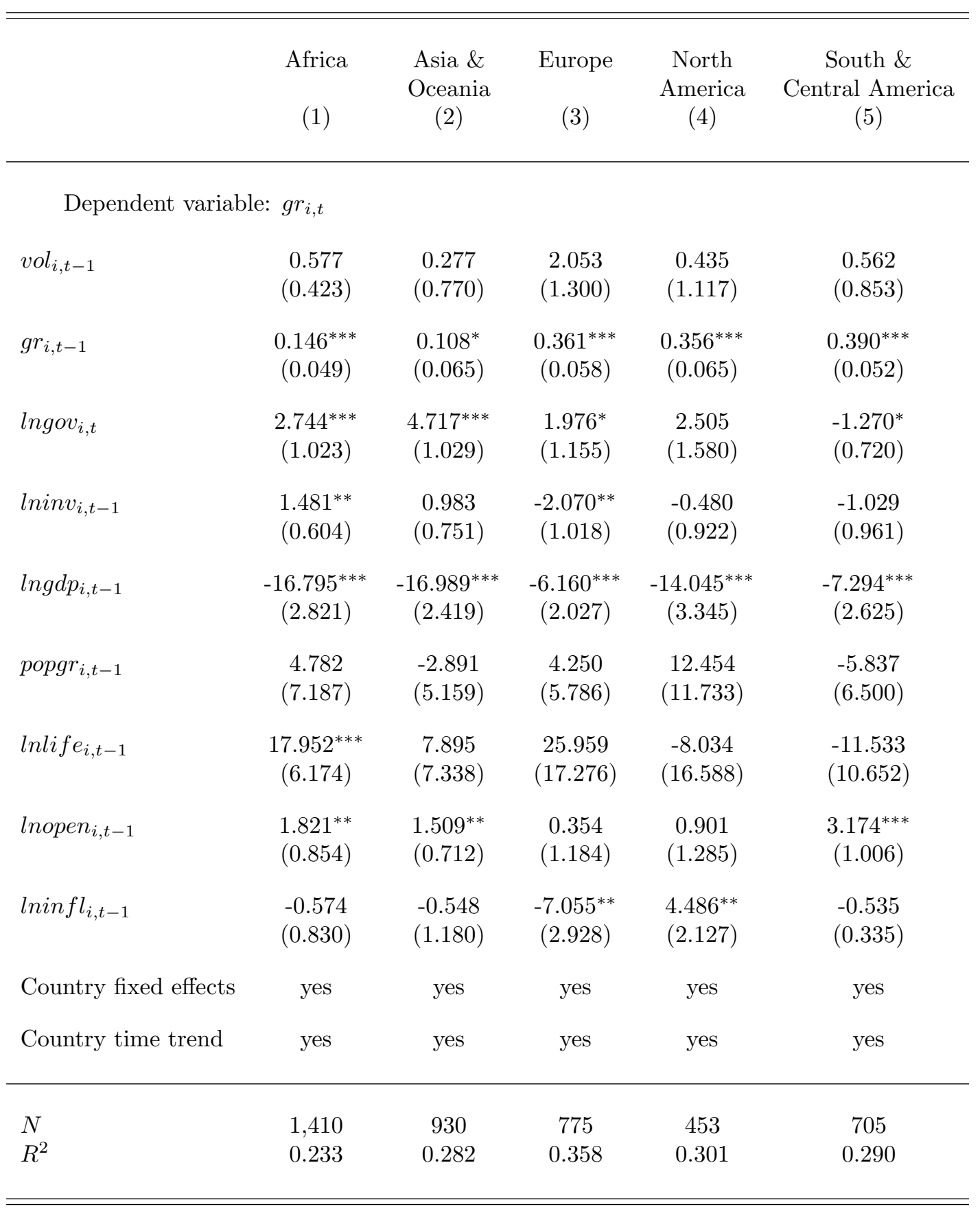

Standard errors in parentheses. ${ }^{*} p<0.10,{ }^{* *} p<0.05,{ }^{* * *} p<0.01$ 
Table A.2: Main OLS regressions (table 3, column 6) by population, time frame, and OECD vs. non-OECD.

\begin{tabular}{|c|c|c|c|c|c|c|}
\hline & $\begin{array}{c}\text { pop }<9.2 M \\
\text { (1) }\end{array}$ & $p o p \underset{(2)}{\geq 9.2 M}$ & $\begin{array}{c}\text { year }<1986 \\
(3)\end{array}$ & $\underset{(4)}{y e a r}>1985$ & $\begin{array}{l}\text { OECD } \\
(5)\end{array}$ & $\begin{array}{c}\text { non-OECD } \\
(6)\end{array}$ \\
\hline \multicolumn{7}{|c|}{ Dependent variable: $g r_{i, t}$} \\
\hline $\operatorname{vol}_{i, t-1}$ & $\begin{array}{c}0.577 \\
(0.433)\end{array}$ & $\begin{array}{c}0.894 \\
(0.762)\end{array}$ & $\begin{array}{c}0.400 \\
(0.428)\end{array}$ & $\begin{array}{c}0.687 \\
(0.532)\end{array}$ & $\begin{array}{c}1.400 \\
(1.201)\end{array}$ & $\begin{array}{c}0.565 \\
(0.389)\end{array}$ \\
\hline$g r_{i, t-1}$ & $\begin{array}{c}0.218^{* * *} \\
(0.040)\end{array}$ & $\begin{array}{c}0.127^{* *} \\
(0.048)\end{array}$ & $\begin{array}{c}0.130^{* * *} \\
(0.041)\end{array}$ & $\begin{array}{c}0.227^{* * * *} \\
(0.045)\end{array}$ & $\begin{array}{c}0.302^{* * *} \\
(0.043)\end{array}$ & $\begin{array}{c}0.184^{* * *} \\
(0.035)\end{array}$ \\
\hline $\operatorname{lngov}_{i, t}$ & $\begin{array}{l}2.148^{* *} \\
(0.994)\end{array}$ & $\begin{array}{c}2.669^{* * *} \\
(0.720)\end{array}$ & $\begin{array}{c}5.136^{* * *} \\
(0.942)\end{array}$ & $\begin{array}{c}3.484^{* * *} \\
(1.175)\end{array}$ & $\begin{array}{l}1.418 \\
(1.017)\end{array}$ & $\begin{array}{c}2.014^{* * *} \\
(0.629)\end{array}$ \\
\hline $\operatorname{lninv} v_{i, t-1}$ & $\begin{array}{l}1.031 \\
(0.647)\end{array}$ & $\begin{array}{c}0.880 \\
(0.596)\end{array}$ & $\begin{array}{c}1.331 \\
(0.871)\end{array}$ & $\begin{array}{c}0.848 \\
(0.856)\end{array}$ & $\begin{array}{l}-1.035 \\
(0.874)\end{array}$ & $\begin{array}{l}1.022^{* *} \\
(0.463)\end{array}$ \\
\hline $\operatorname{lng} d p_{i, t-1}$ & $\begin{array}{c}-19.740^{* * *} \\
(2.767)\end{array}$ & $\begin{array}{c}-12.431^{* * *} \\
(1.901)\end{array}$ & $\begin{array}{c}-23.671^{* * *} \\
(3.304)\end{array}$ & $\begin{array}{c}-24.958^{* * *} \\
(3.289)\end{array}$ & $\begin{array}{c}-7.275^{* * *} \\
(2.155)\end{array}$ & $\begin{array}{c}-15.187^{* * *} \\
(1.938)\end{array}$ \\
\hline popgr $_{i, t-1}$ & $\begin{array}{l}14.233 \\
(9.051)\end{array}$ & $\begin{array}{l}-4.768 \\
(3.567)\end{array}$ & $\begin{array}{l}-2.361 \\
(5.072)\end{array}$ & $\begin{array}{c}1.145 \\
(4.846)\end{array}$ & $\begin{array}{c}4.053 \\
(4.908)\end{array}$ & $\begin{array}{c}0.420 \\
(4.501)\end{array}$ \\
\hline $\operatorname{lnlife}_{i, t-1}$ & $\begin{array}{c}18.544^{* * *} \\
(6.773)\end{array}$ & $\begin{array}{c}14.852^{* * *} \\
(5.030)\end{array}$ & $\begin{array}{l}31.900^{* *} \\
(14.442)\end{array}$ & $\begin{array}{c}29.564^{* * *} \\
(11.336)\end{array}$ & $\begin{array}{c}20.968 \\
(14.220)\end{array}$ & $\begin{array}{c}16.543^{* * *} \\
(5.209)\end{array}$ \\
\hline $\operatorname{lnopen}_{i, t-1}$ & $\begin{array}{c}2.580^{* * * *} \\
(0.823)\end{array}$ & $\begin{array}{c}1.957^{* * *} \\
(0.642)\end{array}$ & $\begin{array}{c}1.723 \\
(1.188)\end{array}$ & $\begin{array}{c}3.871^{* * *} \\
(0.823)\end{array}$ & $\begin{array}{c}0.388 \\
(0.747)\end{array}$ & $\begin{array}{c}2.599^{* * *} \\
(0.564)\end{array}$ \\
\hline $\operatorname{lninfl} l_{i, t-1}$ & $\begin{array}{c}-0.980^{* *} \\
(0.450)\end{array}$ & $\begin{array}{l}-0.928^{*} \\
(0.481)\end{array}$ & $\begin{array}{l}1.857 \\
(1.395)\end{array}$ & $\begin{array}{l}-0.627^{*} \\
(0.370)\end{array}$ & $\begin{array}{c}-3.143^{* *} \\
(1.487)\end{array}$ & $\begin{array}{c}-0.798^{* *} \\
(0.320)\end{array}$ \\
\hline Country fixed effects & yes & yes & yes & yes & yes & yes \\
\hline Country time trend & yes & yes & yes & yes & yes & yes \\
\hline$N$ & 2,131 & 2,142 & 2,017 & 2,256 & 1,164 & 3,109 \\
\hline$R^{2}$ & 0.270 & 0.324 & 0.323 & 0.380 & 0.385 & 0.247 \\
\hline
\end{tabular}

Standard errors in parentheses. ${ }^{*} p<0.10,{ }^{* *} p<0.05,{ }^{* * *} p<0.01$ 
Table A.3: 3SLS results from table 4, displaying remaining coefficients.

\begin{tabular}{|c|c|c|c|c|c|}
\hline & \multicolumn{2}{|c|}{ Full sample } & \multirow{2}{*}{$\begin{array}{c}\text { pol }<0 \\
(3)\end{array}$} & \multirow{2}{*}{$\begin{array}{c}p o l>0 \\
(4)\end{array}$} & \multirow{2}{*}{$\begin{array}{c}\text { Full sample } \\
\text { (5) }\end{array}$} \\
\hline & (1) & $(2)$ & & & \\
\hline \multicolumn{6}{|c|}{ Dependent variable: $g r_{i, t}$} \\
\hline $\operatorname{lninv}_{i, t-1}$ & $\begin{array}{l}1.014^{* * *} \\
(0.284)\end{array}$ & $\begin{array}{c}1.176^{* * *} \\
(0.278)\end{array}$ & $\begin{array}{c}2.389^{* * *} \\
(0.523)\end{array}$ & $\begin{array}{c}-0.776^{* *} \\
(0.362)\end{array}$ & $\begin{array}{c}1.350^{* * *} \\
(0.289)\end{array}$ \\
\hline $\operatorname{lngdp} p_{i, t-1}$ & $\begin{array}{l}-11.738^{* * *} \\
(0.849)\end{array}$ & $\begin{array}{c}-11.352^{* * *} \\
(0.846)\end{array}$ & $\begin{array}{c}-16.168^{* * *} \\
(1.551)\end{array}$ & $\begin{array}{c}-5.513^{* * *} \\
(1.271)\end{array}$ & $\begin{array}{c}-11.801^{* * *} \\
(0.862)\end{array}$ \\
\hline $\operatorname{popgr}_{i, t-1}$ & $\begin{array}{l}0.781 \\
(3.278)\end{array}$ & $\begin{array}{c}1.983 \\
(3.210)\end{array}$ & $\begin{array}{l}-1.094 \\
(5.560)\end{array}$ & $\begin{array}{c}0.411 \\
(3.506)\end{array}$ & $\begin{array}{c}2.226 \\
(3.189)\end{array}$ \\
\hline $\operatorname{lnlife} e_{i, t-1}$ & $\begin{array}{l}17.315^{* * *} \\
(1.962)\end{array}$ & $\begin{array}{c}17.950^{* * *} \\
(1.935)\end{array}$ & $\begin{array}{c}26.666^{* * *} \\
(3.225)\end{array}$ & $\begin{array}{c}13.936^{* * *} \\
(2.896)\end{array}$ & $\begin{array}{c}17.601^{* * *} \\
(1.984)\end{array}$ \\
\hline lnopen $_{i, t-1}$ & $\begin{array}{l}2.609^{* * *} \\
(0.379)\end{array}$ & $\begin{array}{c}2.726^{* * *} \\
(0.380)\end{array}$ & $\begin{array}{c}3.278^{* * *} \\
(0.702)\end{array}$ & $\begin{array}{c}1.676^{* * *} \\
(0.467)\end{array}$ & $\begin{array}{c}3.000^{* * *} \\
(0.386)\end{array}$ \\
\hline $\operatorname{lninf} l_{i, t-1}$ & $\begin{array}{l}-0.983^{* * *} \\
(0.257)\end{array}$ & $\begin{array}{c}-1.137^{* * *} \\
(0.252)\end{array}$ & $\begin{array}{c}0.150 \\
(0.695)\end{array}$ & $\begin{array}{c}-0.574^{* *} \\
(0.286)\end{array}$ & $\begin{array}{c}-1.190^{* * *} \\
(0.250)\end{array}$ \\
\hline $\begin{array}{l}\text { Country fixed ef- } \\
\text { fects \& time trends }\end{array}$ & yes & yes & yes & yes & yes \\
\hline $\begin{array}{l}\operatorname{vol}_{i, t-1}, \quad \operatorname{lngov}_{i, t}, \\
\operatorname{gr}_{i, t-1}\end{array}$ & yes & yes & yes & yes & yes \\
\hline $\begin{array}{l}\operatorname{vol}_{i, t-1} \times \operatorname{pol}_{i, t-1}, \\
\operatorname{pol}_{i, t-1}\end{array}$ & & & & & yes \\
\hline \multicolumn{6}{|c|}{ Dependent variable: $\operatorname{lngov}_{i, t}$} \\
\hline $\operatorname{lngd} p_{i, t-1}$ & & $\begin{array}{c}0.309^{* * *} \\
(0.023)\end{array}$ & $\begin{array}{c}0.375^{* * *} \\
(0.048)\end{array}$ & $\begin{array}{c}0.396^{* * *} \\
(0.027)\end{array}$ & $\begin{array}{c}0.325^{* * *} \\
(0.026)\end{array}$ \\
\hline $\operatorname{lnopen}_{i, t-1}$ & & $\begin{array}{l}0.028^{* *} \\
(0.012)\end{array}$ & $\begin{array}{l}0.045^{* *} \\
(0.022)\end{array}$ & $\begin{array}{l}-0.006 \\
(0.013)\end{array}$ & $\begin{array}{l}0.022^{*} \\
(0.013)\end{array}$ \\
\hline $\operatorname{lnpop} p_{i, t-1}$ & & $\begin{array}{l}-0.044 \\
(0.043)\end{array}$ & $\begin{array}{l}-0.045 \\
(0.075)\end{array}$ & $\begin{array}{c}-0.125^{* *} \\
(0.062)\end{array}$ & $\begin{array}{l}-0.056 \\
(0.045)\end{array}$ \\
\hline $\begin{array}{l}\text { Country fixed ef- } \\
\text { fects \& time trends }\end{array}$ & yes & yes & yes & yes & yes \\
\hline $\begin{array}{l}\operatorname{vol}_{i, t-1}, \\
\operatorname{lngov}_{i, t-1}\end{array} \quad \operatorname{gr}_{i, t}$ & yes & yes & yes & yes & yes \\
\hline $\begin{array}{l}\operatorname{vol}_{i, t-1} \times \operatorname{pol}_{i, t-1}, \\
\operatorname{pol}_{i, t-1}\end{array}$ & & & & & yes \\
\hline$N$ & 4,266 & 4,266 & 1,651 & 2,536 & 3,974 \\
\hline
\end{tabular}

Standard errors in parentheses. ${ }^{*} p<0.10,{ }^{* *} p<0.05,{ }^{* * *} p<0.01$ 
Table A.4: 3SLS results, only using observations for which information for all variables is available.

\begin{tabular}{|c|c|c|c|c|c|}
\hline & \multicolumn{2}{|c|}{ Full sample } & \multirow{2}{*}{$\begin{array}{c}p o l<0 \\
(3)\end{array}$} & \multirow{2}{*}{$\begin{array}{c}p o l>0 \\
(4)\end{array}$} & \multirow{2}{*}{$\begin{array}{c}\text { Full sample } \\
\text { (5) }\end{array}$} \\
\hline & (1) & (2) & & & \\
\hline \multicolumn{6}{|c|}{ Dependent variable: $g r_{i, t}$} \\
\hline $\operatorname{vol}_{i, t-1}$ & $\begin{array}{c}0.567^{* * *} \\
(0.100)\end{array}$ & $\begin{array}{c}0.584^{* * *} \\
(0.100)\end{array}$ & $\begin{array}{c}0.901^{* * *} \\
(0.144)\end{array}$ & $\begin{array}{l}0.286 \\
(0.177)\end{array}$ & $\begin{array}{c}0.324^{* *} \\
(0.141)\end{array}$ \\
\hline $\operatorname{lngov}_{i, t}$ & $\begin{array}{c}-1.095^{* *} \\
(0.452)\end{array}$ & $\begin{array}{c}-1.431^{* * *} \\
(0.452)\end{array}$ & $\begin{array}{c}-1.891^{* *} \\
(0.912)\end{array}$ & $\begin{array}{c}-1.403^{* *} \\
(0.648)\end{array}$ & $\begin{array}{l}-1.472^{* * *} \\
(0.452)\end{array}$ \\
\hline$g r_{i, t-1}$ & $\begin{array}{c}0.148^{* * *} \\
(0.016)\end{array}$ & $\begin{array}{c}0.142^{* * *} \\
(0.016)\end{array}$ & $\begin{array}{c}0.080^{* * *} \\
(0.024)\end{array}$ & $\begin{array}{c}0.243^{* * *} \\
(0.021)\end{array}$ & $\begin{array}{c}0.138^{* * *} \\
(0.016)\end{array}$ \\
\hline $\operatorname{vol}_{i, t-1} \times \operatorname{pol}_{i, t-1}$ & & & & & $\begin{array}{c}-0.061^{* * *} \\
(0.023)\end{array}$ \\
\hline pol $_{i, t-1}$ & & & & & $\begin{array}{l}0.039^{*} \\
(0.022)\end{array}$ \\
\hline $\begin{array}{l}\text { Country fixed effects } \\
\& \text { time trends }\end{array}$ & yes & yes & yes & yes & yes \\
\hline Control sets $^{a}$ & yes & yes & yes & yes & yes \\
\hline $\begin{array}{l}\text { F-test joint insignif- } \\
\text { icance of IVs }{ }^{b}\end{array}$ & $27.74^{* * *}$ & $13.98^{* * *}$ & $3.94^{* * *}$ & $14.30^{* * *}$ & $13.55^{* * *}$ \\
\hline
\end{tabular}

\begin{tabular}{|c|c|c|c|c|c|}
\hline \multicolumn{6}{|c|}{ Dependent variable: $\operatorname{lngov}_{i, t}$} \\
\hline $\operatorname{vol}_{i, t-1}$ & $\begin{array}{l}0.005^{*} \\
(0.003)\end{array}$ & $\begin{array}{l}0.005^{*} \\
(0.003)\end{array}$ & $\begin{array}{l}-0.001 \\
(0.004)\end{array}$ & $\begin{array}{c}0.014^{* * *} \\
(0.005)\end{array}$ & $\begin{array}{c}0.011^{* * *} \\
(0.004)\end{array}$ \\
\hline$g r_{i, t} 0.004^{* * *}$ & $\begin{array}{c}0.014^{* * *} \\
(0.001)\end{array}$ & $\begin{array}{c}0.012^{* * *} \\
(0.002)\end{array}$ & $\begin{array}{c}0.008^{* * *} \\
(0.003)\end{array}$ & $\begin{array}{c}0.015^{* * *} \\
(0.002)\end{array}$ & $(0.002)$ \\
\hline $\operatorname{lngov}_{i, t-1}$ & $\begin{array}{c}0.861^{* * *} \\
(0.009)\end{array}$ & $\begin{array}{c}0.792^{* * *} \\
(0.010)\end{array}$ & $\begin{array}{c}0.730^{* * *} \\
(0.018)\end{array}$ & $\begin{array}{c}0.724^{* * *} \\
(0.014)\end{array}$ & $\begin{array}{c}0.793^{* * *} \\
(0.010)\end{array}$ \\
\hline $\operatorname{vol}_{i, t-1} \times \operatorname{pol}_{i, t-1}$ & & & & & $\begin{array}{l}0.001^{* *} \\
(0.001)\end{array}$ \\
\hline $\operatorname{pol}_{i, t-1}$ & & & & & $\begin{array}{l}-0.001 \\
(0.001)\end{array}$ \\
\hline $\begin{array}{l}\text { Country fixed effects } \\
\& \text { time trends }\end{array}$ & yes & yes & yes & yes & yes \\
\hline Control set ${ }^{c}$ & & yes & yes & yes & yes \\
\hline $\begin{array}{l}\text { F-test joint insignif- } \\
\text { icance of } \mathrm{IVs}^{d}\end{array}$ & $1,413.57^{* * *}$ & $468.64^{* * *}$ & $168.70^{* * *}$ & $162.73^{* * *}$ & $478.13^{* * *}$ \\
\hline$N$ & 3,974 & 3,974 & 1,650 & 2,244 & 3,974 \\
\hline
\end{tabular}

Notes: Standard errors in parentheses. ${ }^{*} p<0.10,{ }^{* *} p<0.05,{ }^{* * *} p<0.01$.

${ }^{a}$ Control variables from Levine and Renelt (1992) and Mirestean and Tsangarides (2009): investment $\left(\operatorname{lnin} v_{i, t-1}\right)$, GDP $\left(\operatorname{lng} d p_{i, t-1}\right)$, population growth $\left(\right.$ popgr $\left._{i, t-1}\right)$,

life expectancy, $\left(\operatorname{lnlife}_{i, t-1}\right)$, openness to trade $\left(\operatorname{lnopen}_{i, t-1}\right)$,

and inflation $\left(\operatorname{lnin} f l_{i, t-1}\right)$.

${ }^{b}$ IVs are regressors exclusively used in the growth equation.

${ }^{c}$ Control variables from Shelton (2007): GDP $\left(\operatorname{lng} d p_{i, t-1}\right)$, trade openness $\left(\operatorname{lnopen}_{i, t-1}\right)$, and population size $\left(\operatorname{lnpop}_{i, t-1}\right)$.

${ }^{d}$ IVs are regressors exclusively used in the government size equation. 